\title{
Medical interventions for fungal keratitis (Review)
}

\author{
FlorCruz NV, Peczon IV, Evans JR
}

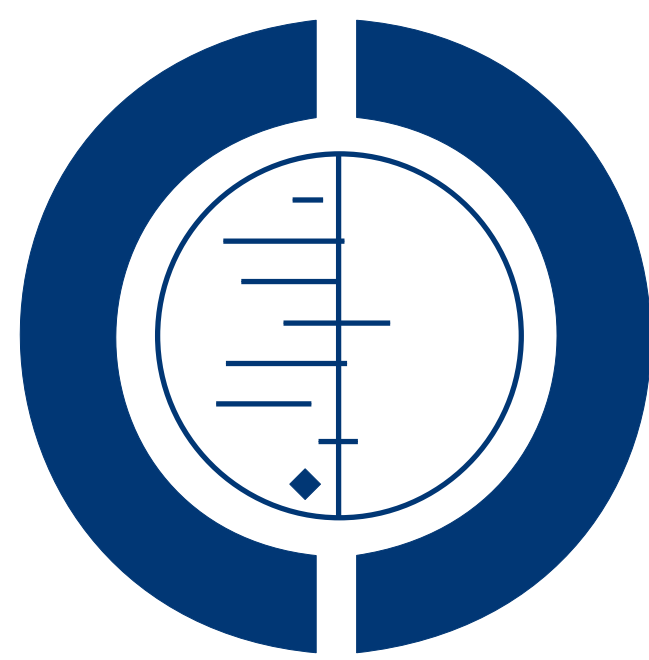

THE COCHRANE COLLABORATION ${ }^{\circledR}$

This is a reprint of a Cochrane review, prepared and maintained by The Cochrane Collaboration and published in The Cochrane Library 2012, Issue 2

http://www.thecochranelibrary.com

\section{WILEY}


TABLE OF CONTENTS

HEADER . . . . . . . . . . . . . . . . . . . . . . . . . . . . . . . . . . . . . . . 1

ABSTRACT . . . . . . . . . . . . . . . . . . . . . . . . . . . . . . . . . . . . . . . . . . . .

PLAIN LANGUAGE SUMMARY . . . . . . . . . . . . . . . . . . . . . . . . . . . . . . . . . . . 2

BACKGROUND . . . . . . . . . . . . . . . . . . . . . . . . . . . . . . . . . . . . . .

OBJECTIVES . . . . . . . . . . . . . . . . . . . . . . . . . . . . . . . . . . . . . . . . . . . . . .

METHODS . . . . . . . . . . . . . . . . . . . . . . . . . . . . . . . . . . . . . . 3

RESULTS . . . . . . . . . . . . . . . . . . . . . . . . . . . . . . . . 5

Figure 1. . . . . . . . . . . . . . . . . . . . . . . . . . . . . . . . . . . . . 7

Figure 2. . . . . . . . . . . . . . . . . . . . . . . . . . . . . . . . . . . . . . . . . . 8

DISCUSSION . . . . . . . . . . . . . . . . . . . . . . . . . . . . . . . . . . . . . . . . . . . . . . . . .

AUTHORS' CONCLUSIONS . . . . . . . . . . . . . . . . . . . . . . . . . . . . . . . . . . . .

ACKNOWLEDGEMENTS . . . . . . . . . . . . . . . . . . . . . . . . . . . . . . . . . . . . . . . .

REFERENCES . . . . . . . . . . . . . . . . . . . . . . . . . . . . . . . . . . . . . . 11

CHARACTERISTICS OF STUDIES . . . . . . . . . . . . . . . . . . . . . . . . . . . . . . 12

DATA AND ANALYSES . . . . . . . . . . . . . . . . . . . . . . . . . . . . . . . . . . . . . . 28

Analysis 1.1. Comparison 1 1\% silver sulphadiazine versus $1 \%$ miconazole, Outcome 1 Ulcer healed at 2 to 4 weeks. 28

Analysis 2.1. Comparison 2 Chlorhexidine versus natamycin, Outcome 1 Favourable response at 5 days. . . . . . 29

Analysis 2.2. Comparison 2 Chlorhexidine versus natamycin, Outcome 2 Ulcer healed at 21 days. . . . . . . . $\quad 29$

ADDITIONAL TABLES . . . . . . . . . . . . . . . . . . . . . . . . . . . . . . . . . . . . . 30

APPENDICES . . . . . . . . . . . . . . . . . . . . . . . . . . . . . . . . . . . . . . . . . . . .

WHAT'S NEW . . . . . . . . . . . . . . . . . . . . . . . . . . . . . . . . . . . . . . 34

HISTORY . . . . . . . . . . . . . . . . . . . . . . . . . . . . . . . . . . . . . . . 34

CONTRIBUTIONS OF AUTHORS . . . . . . . . . . . . . . . . . . . . . . . . . . . . . . . . . 35

DECLARATIONS OF INTEREST . . . . . . . . . . . . . . . . . . . . . . . . . . . . . . . . . . . . . . . . .

SOURCES OF SUPPORT . . . . . . . . . . . . . . . . . . . . . . . . . . . . . . . . . . 35

INDEX TERMS . . . . . . . . . . . . . . . . . . . . . . . . . . . . . . . . . . . . . . . . . . . . . . . .

Medical interventions for fungal keratitis (Review)

Copyright $\odot 2012$ The Cochrane Collaboration. Published by John Wiley \& Sons, Ltd. 


\title{
[Intervention Review] \\ Medical interventions for fungal keratitis
}

\author{
Nilo Vincent FlorCruz ${ }^{1}$, Ildefonso V Peczon ${ }^{2}$, Jennifer R Evans ${ }^{3}$ \\ ${ }^{1}$ Department of Ophthalmology and Visual Sciences, University of the Phillipines-Philippine General Hospital, Manila, Philippines. \\ ${ }^{2}$ Department of Ophthalmology and Visual Sciences, Sentro Oftalmologico Jose Rizal, Manila, Philippines. ${ }^{3}$ Cochrane Eyes and Vision \\ Group, ICEH, London School of Hygiene \& Tropical Medicine, London, UK
}

Contact address: Nilo Vincent FlorCruz, Department of Ophthalmology and Visual Sciences, University of the Phillipines-Philippine General Hospital, Taft Avenue, Manila, 1000, Philippines. docnilo11@gmail.com.

Editorial group: Cochrane Eyes and Vision Group.

Publication status and date: New search for studies and content updated (no change to conclusions), published in Issue 2, 2012.

Review content assessed as up-to-date: 29 August 2011.

Citation: FlorCruz NV, Peczon IV, Evans JR. Medical interventions for fungal keratitis. Cochrane Database of Systematic Reviews 2012, Issue 2. Art. No.: CD004241. DOI: 10.1002/14651858.CD004241.pub3.

Copyright (C) 2012 The Cochrane Collaboration. Published by John Wiley \& Sons, Ltd.

\begin{abstract}
A B S T R A C T
Background

Fungal keratitis is a fungal infection of the cornea. It is common in agricultural tropical countries but relatively uncommon in developed countries. Although there are medications available, their effectiveness is unclear.
\end{abstract}

\section{Objectives}

To examine the effect of different antifungal drugs in the management of fungal keratitis.

\section{Search methods}

We searched CENTRAL (which contains the Cochrane Eyes and Vision Group Trials Register) (The Cochrane Library 2011, Issue 8), MEDLINE (January 1950 to August 2011), EMBASE (January 1980 to August 2011), Latin American and Caribbean Literature on Health Sciences (LILACS) (January 1982 to August 2011), the metaRegister of Controlled Trials ( $m$ RCT) (www.controlled-trials.com) and ClinicalTrials.gov (www.clinicaltrials.gov). There were no date or language restrictions in the electronic searches for trials. The electronic databases were last searched on 29 August 2011.

\section{Selection criteria}

We included all relevant randomised controlled trials (RCTs) on medical therapy for fungal keratitis.

\section{Data collection and analysis}

Two review authors selected studies for inclusion into the review, assessed trials for risk of bias and extracted data. Interventions were compared by the proportions of participants that did not heal after a specific time of therapy. No meta-analysis was performed because the trials studied different medications with different concentrations.

\section{Main results}

We included nine trials in this review; seven conducted in India, one in Bangladesh and one in Egypt. A total of 568 participants were randomised to the following comparisons: $1 \%$ topical itraconazole versus $1 \%$ topical itraconazole and oral itraconazole, different concentrations of silver sulphadiazine versus $1 \%$ miconazole, $1 \%$ silver sulphadiazine ointment versus $1 \%$ miconazole ointment, $2 \%$ econazole versus $5 \%$ natamycin, different concentrations of topical chlorhexidine gluconate versus $5 \%$ natamycin, $0.2 \%$ chlorhexidine gluconate versus $2.5 \%$ natamycin and voriconazole $1 \%$ versus natamycin $5 \%$. The included trials were small and of variable quality. Differences between different regimens were not statistically different, which may reflect the low sample sizes.

Medical interventions for fungal keratitis (Review)

Copyright $\odot 2012$ The Cochrane Collaboration. Published by John Wiley \& Sons, Ltd. 


\section{Authors' conclusions}

Based on the trials included in this review, there is no evidence to date that any particular drug, or combination of drugs, is more effective in the management of fungal keratitis. The trials included in this review were of variable quality and were generally underpowered.

\section{PLAIN LANGUAGESUMMARY}

\section{Medical interventions for fungal infection of the clear front part of the eye (cornea)}

Fungal keratitis (fungal infection of the cornea) occurs rarely in higher income countries but is relatively common in lower income countries. If left untreated the cornea may perforate and may lead to blindness. Although there are a number of medications available, it is not clear which is the most effective and cost-effective. This review identified nine randomised controlled trials with 568 participants using different combinations of antifungal drugs. The trials were mainly conducted in India; they were small and of variable quality. Although there were some observed differences, these could have occurred by chance; none of the studies were large enough to determine conclusively which agents work best. Further trials with a larger sample size are required in order to answer this important question.

\section{B A C K G R O U N D}

\section{Description of the condition}

Fungal infections can involve different parts of the eye and periocular tissues including the lacrimal apparatus, conjunctiva, eyelids and bony orbit. The most common sites for fungal infections of the eye involve the cornea and the retina or vitreous ( $\mathrm{O}^{\prime}$ Brien 1997). In the past few decades there have been increased reports of fungal infections of the eye (O'Day 1996). These can be mainly attributed to increased clinical awareness and improved laboratory techniques and may also have been caused by widespread use of corticosteroids, antibiotics, immunosuppressants, chemotherapeutic drugs and ocular prosthetic devices (O’ Brien 1997).

\section{Epidemiology}

Fungal keratitis or keratomycosis is relatively uncommon in developed countries. There have been no high quality published reports on the incidence rates of the disease. In the United States, it has been reported that the total number of fungal keratitis cases annually is approximately 1500 (O' Day 1996). It is, however, more common in agricultural and tropical countries. In South Florida, a nine year survey from 1968 to 1977 revealed that 133 out of 633 cases of corneal ulcers were fungal in origin (Liesegang 1980). In the Philippines, a 25 year survey on central microbial keratitis revealed a total of 430 cases (Valenton 2000). The most common etiologic agents are Fusarium, Aspergillus fumigatus and Aspergillus flavus. In Hyderabad, India, a ten year study on fungal keratitis showed 1,352 culture proven cases, the most common etiologic agents included Fusarium, Aspergillus, and Curvularia spp (Gopinathan 2002).

The most common predisposing factor in fungal keratitis is trauma associated with plant material. Other risk factors include longterm corticosteroid use and immuno-compromised patients $\left(\mathrm{O}^{\prime}\right.$ Day 1996).

\section{Presentation and diagnosis}

Fungal infections almost always present in an insidious manner. The infection may be recognised within days or weeks and it is not uncommon for the traumatised epithelium to heal completely before signs of infection appear. During this latent period the patient may be asymptomatic. However, within a few days or weeks the patient might complain of discomfort, photophobia and discharge.

During this period, a persistent infiltrate at the site of previous superficial trauma is present which may increase in size and density in time. The epithelium tends to heal over this inflammatory focus, although there may be recurrent episodes of epithelial breakdown. The cornea becomes slightly thickened and 'satellite' lesions may develop peripheral to the focal area of infiltration.

If not treated, the inflammatory signs gradually progress causing permanent breakdown of the epithelium, stromal ulceration, or formation of descemetocoele (corneal thinning). The cornea may eventually perforate. Neovascularisation may occur as a result of inflammation, which may lead to severe scarring of the cornea. Associated signs indicating the severity of inflammation include the presence of hypopyon (pus in the anterior chamber) and ciliary injection. Fungi can invade the deep stroma with great rapidity 
and may gain access to the anterior chamber.

It is important to determine the etiologic agent of the corneal ulcer. Combined infections with bacteria and fungi or even with multiple fungi might occur. Diagnosis is usually achieved by scraping material from the base of the ulcer. Some of this material is stained for fungi and bacteria, the rest is cultured on solid and liquid media. In severe cases where diagnosis is unclear it may be necessary to take a larger corneal biopsy.

\section{Description of the intervention}

Management of fungal keratitis is mainly by antifungal agents. Keratoplasty or corneal transplant is usually reserved for acute management of corneal perforation and for visual rehabilitation following corneal scarring.

The number of antifungal agents available for therapy is few compared with the number of pathogens capable of infecting the eye (O' Brien 1997). Current antifungal agents are divided into four groups: polyenes, imidazoles, triazoles and fluorinated pyrimidines. These drugs can be administered topically, intravenously or orally. Topical antifungals can cause toxicity such as punctate keratitis, chemosis recurrent corneal epithelial erosions and conjunctival injection. Sub-conjunctival injections are quite painful and ulceration and necrosis of the conjunctival epithelium may occur.

Current practice in the treatment of fungal keratitis involves the use of topical antifungal drops such as natamycin and topical amphotericin B. Newly discovered triazoles such as voriconazole and posaconazole are also being studied as treatment for fungal keratitis (Galarreta 2007; Tu 2007). In developing countries, where the incidence of fungal keratitis is higher, the costs and availability of these polyene drops may be an issue. Hence, various studies have been performed to validate the effectiveness of chlorhexidine drops as an inexpensive alternative to the treatment of fungal keratitis (Martin 1996). Combination therapy using several antifungal drugs has been studied. The concomitant use of corticosteroids and antifungal agents remains controversial (O' Brien 1997).

In India, due to unavailability and high price of antifungal drugs, different antiseptic agents were studied in vitro and revealed a good dose response for chlorhexidine gluconate while povidone iodone showed a good response in all concentrations (Martin 1996). This initial study was then followed by a randomised controlled trial (RCT) to further determine the clinical effectiveness of chlorhexidine in confirmed fungal keratitis patients (Rahman 1997).

\section{How the intervention might work}

Antifungal medications such as the polyenes work by binding to the ergosterol in the cell membrane of the fungal organism. Likewise, imdazoles affect the plasma membrane formation by affecting the ergosterol through microsomal P-450 enzyme. Pyrimidines are transformed to fluorouracil in the cell, therefore blocking the thymidine synthesis (Mabon 1998).

\section{Why it is important to do this review}

The gold standard for the treatment of fungal keratitis has not been identified. Due to the low incidence of the disease it is difficult to perform large trials, especially in developed countries. A systematic review of available trials will, therefore, contribute to the evidence base.

\section{O B J E C T I V E S}

To assess the effects of different antifungal drugs in the management of fungal keratitis.

\section{METHODS}

\section{Criteria for considering studies for this review}

\section{Types of studies}

We considered only RCTs in this review.

\section{Types of participants}

We included trials where the participants had fungal keratitis diagnosed clinically or microbiologically. We also included trials which included both people with or without corneal perforation, if separate data were available for those without perforation. We excluded studies of participants with mixed bacterial and fungal infections.

\section{Types of interventions}

We considered studies using various antifungal drugs in the management of fungal keratitis. This included placebo controlled trials or trials comparing one antifungal agent against another. We also considered trials comparing antifungal drugs with superficial keratectomy.

\section{Types of outcome measures}

\section{Primary outcomes}

1. Clinical improvement: defined as lessening of pain, decrease in size of infiltrate, disappearance of satellite lesions, rounding 
out of feathery margins of the ulcer, disappearance of hypopyon, decrease congestion and healing of epithelium defect. Clinical improvement was assessed on a weekly basis.

2. Clinical cure: defined as healing of the corneal epithelium with scarring of the cornea. Clinical cure was assessed as absence of epithelial defect, absence of cellular reaction in the anterior chamber, presence of corneal vessels and scarring. Clinical cure was usually expected between six to eight weeks. Time to clinical cure was a measured outcome.

\section{Secondary outcomes}

1. recurrence;

2. therapeutic success based on the initial size of ulcer;

3. cost-effectiveness of treatment;

4. compliance with treatment;

5. complications: number of participants that experienced complications of fungal keratitis. Complications may include corneal thinning or descemetocoele formation, corneal perforation and endophthalmitis;

6. adverse outcomes as reported in trials. These include: chemosis, punctate keratopathy, recurrent epithelial erosions, conjunctival injections, ulceration and necrosis of conjunctiva, hepatotoxicity and renal toxicity;

7. quality of life.

\section{Follow up}

We included trials with at least two months follow up.

\section{Search methods for identification of studies}

\section{Electronic searches}

We searched the Cochrane Central Register of Controlled Trials (CENTRAL) 2011, Issue 8, part of The Cochrane Library. www.thecochranelibrary.com (accessed 29 August 2011), MEDLINE (January 1950 to August 2011), EMBASE (January 1980 to August 2011), Latin American and Caribbean Literature on Health Sciences (LILACS) (January 1982 to August 2011), the metaRegister of Controlled Trials ( $m$ RCT) (www.controlledtrials.com) and ClinicalTrials.gov (www.clinicaltrials.gov). There were no language or date restrictions in the search for trials. The electronic databases were last searched on 29 August 2011.

See: Appendices for details of search strategies for CENTRAL (Appendix 1), MEDLINE (Appendix 2), EMBASE (Appendix 3), LILACS (Appendix 4), $m$ RCT (Appendix 5) and ClinicalTrials.gov (Appendix 6).

\section{Searching other resources}

We searched the reference lists of identified trial reports to find additional trials. We contacted investigators and pharmaceutical companies to identify additional published, unpublished and ongoing studies. We used the Science Citation Index to find studies that have cited the identified trials. We searched conference abstracts for additional studies but journals were not handsearched.

\section{Data collection and analysis}

\section{Selection of studies}

Titles and abstracts resulting from the searches were reviewed independently by two review authors against the inclusion criteria for the review. We obtained full copies of the studies that definitely or possibly met the inclusion criteria for further assessment on whether the paper should be excluded or included. We contacted trialists for further information in order to determine the relevance of the study.

\section{Data extraction and management}

Two review authors extracted details about the methods, participants, interventions, outcomes measured and other details of the included studies and transferred them to the 'Characteristics of included studies' table in RevMan (Review Manager 2011). One review author extracted data using the form developed by the Cochrane Eyes and Vision Group. A second author compared the extraction to the original reports. If data were missing or difficult to determine from a paper, the trialists were approached for clarification and verification. Data were entered into RevMan by one review author, and the second author checked for errors.

\section{Assessment of risk of bias in included studies}

Assessment of the risk of bias of studies was undertaken in accordance with the methods given in Chapter 8 the Cochrane Handbook for Systematic Reviews of Intervention (Higgins 2011). Two review authors independently assessed the studies and disagreements between authors were resolved by discussion. Four bias domains were considered: selection bias, performance bias, detection bias and attrition bias. Assessment was based on the following questions:

1. Selection bias (random sequence generation and allocation concealment): was the sequence of allocation of participants to groups randomly generated and concealed until after treatments were allocated?

2. Performance bias (masking of participants and researchers): were the recipients of care unaware of their assigned treatment? Were persons providing care unaware of the assigned treatment?

3. Detection bias: were persons assessing outcome unaware of the assigned treatment?

4. Attrition bias: were rates of follow up similar in the comparison groups? Was the analysis 'intention-to-treat' (were all participants analysed as randomised)? 
We assessed each parameter as 'low risk of bias', 'high risk of bias' or unclear. We contacted trialists for clarification of any parameter graded as unclear. In the protocol we planned to conduct a sensitivity analysis excluding studies at high risk of bias: the current review does not include any meta-analysis so that was not done.

\section{Data synthesis}

We presented summary measures for dichotomous data as relative risk ratios. For continuous data we calculated the weighted mean difference. We presented the point estimate and confidence intervals with a 95\% confidence interval for individual results.

We did not pool data from the individual trials but in the protocol we specified that we would use the fixed-effect model if the total number of trials in the comparison was three or less provided that heterogeneity had not been detected either statistically or by review. If the number of trials was more than three we planned to use the random-effects model.

\section{Sensitivity analysis}

We did not conduct sensitivity analysis as we did not do a metaanalysis. If possible we will do so for future updates so that we can assess how robust the review results were to key decisions and assumptions that were made during the review. Analysis of data will be repeated with the following adjustments:

1. exclusion of studies at greater risk of bias;

2. exclusion of unpublished studies;

3. changing inclusion criteria such as lowering methodological cut-off points.

\section{R E S U L T S}

\section{Description of studies}

See: Characteristics of included studies; Characteristics of excluded studies; Characteristics of ongoing studies.

\section{Results of the search}

The electronic searches resulted in 471 reports of possible medical interventions for fungal keratitis. Twenty three abstracts were retrieved in full for further assessment. Six RCTs were identified for inclusion (Agarwal 2001; Mohan 1987; Mohan 1988; Prajna 2003; Rahman 1997; Rahman 1998).

An updated search was done in January 2007 and Februrary 2010. The searches yielded a total 206 and 23 references respectively. The Trials Search Co-ordinator (TSC) scanned the search results for both updates and removed any references which were not relevant to the scope of the review. The update searches did not identify any references which met the inclusion criteria for the review.

A further update search was done in August 2011. After deduplication the search identified a total of 50 references. The TSC scanned the search results and removed 41 references which were not relevant to the scope of the review. We reviewed the remaining nine references of which five were published reports of studies and four were reports of ongoing studies. We assessed the five published reports of studies for potential inclusion in the review. We obtained full-text copies of three studies and have included them in the review (Arora 2011; Mahdy 2010; Prajna 2010). The remaining two reports did not meet the inclusion criteria. Of the four reports of ongoing studies trial NCT00557362 is the initial report of the published paper by Prajna 2010. The three other reports of ongoing studies are relevant to the review and have been added to the studies awaiting assessment section and the results will be included in the review when the studies have been completed (NCT00996736; NCT00997035; NCT00516399).

Contact with first authors of identified trials and searching the reference lists of these studies failed to identify any additional trials. We also approached pharmaceutical companies producing antifungal agents but there was no information on additional trials.

\section{Included studies}

See the 'Characteristics of included studies' table for additional details for included studies.

\section{Size of studies}

The nine included trials randomised a total of 568 participants: Agarwal 2001 (54 participants); Arora 2011 (30); Mahdy 2010 (48); Mohan 1987 (30) Mohan 1988 (40); Prajna 2003 (116); Prajna 2010 (120); Rahman 1997 (60); Rahman 1998 (70).

\section{Types of participants}

Seven of the trials were conducted in India with one trial conducted in Bangladesh (Rahman 1998) and one trial in Egypt (Mahdy 2010). Trials included people with a wide range of ages, from seven to 84 years of age, although in general the patient populations were younger rather than older, with average ages less than 50 years. The majority of the participants were male; the percentage male ranged from $64 \%$ to $78 \%$ in the included trials.

The majority of the trials included participants with microbiological evidence of fungal keratitis. Two trials (Agarwal 2001; Mahdy 2010) included participants based on a clinical definition only.

\section{Types of interventions}

Table 1 summarises the antifungals studied. The trials were heterogenous in terms of types of antifungals studied. Seven antifungal drugs in different preparations and routes of administration 
were used. Agarwal 2001 compared topical and systemic itraconazole versus topical itraconazole. Mohan 1987 compared $0.5 \%$ and $1 \%$ silver sulphadiazine in ointment form to $1 \%$ miconazole ointment while Mohan 1988 compared 1\% silver sulphadiazine versus 1\% miconazole ointment. Prajna 2003 compared 2\% econazole and 5\% natamycin in topical preparations. Rahman 1997 compared different concentrations of chlorhexidine gluconate versus 5\% natamycin while Rahman 1998 compared 0.2\% chlorhexidine gluconate versus $2.5 \%$ natamycin. Arora 2011 and Prajna 2010 compared topical voriconazole $1 \%$ with natamycin $5 \%$ and Mahdy 2010 compared amphotericin B combined with subconjunctival injection of fluconazole with amphotericin B alone.

Agarwal 2001, Mohan 1987 and Mohan 1988 were cross-over trials. Data on the first treatment was used for the review.

\section{Types of outcome measures}

The majority of trials considered healing of ulcer, or time taken for ulcer to heal, as the primary outcome. Prajna 2010 specified visual acuity as the primary outcome. Follow-up varied: Rahman
1997 and Rahman 1998 considered healing of ulcer at three weeks; Mohan 1987 and Prajna 2003 considered healing at four weeks; Mohan 1988 did not specify a cut-off time but noted healing of ulcers within two to four weeks; Agarwal 2001 considered healing of ulcer at six weeks as primary outcome; Arora 2011 followed up for a minimum of 10 weeks, or until the ulcer healed; Prajna 2010 specified the main outcome at three months; and Mahdy 2010 also followed up for three months. The trials noted a healed ulcer based on slit lamp findings such as disappearance of hypopyon and circumoral congestion, absence of fluorescein staining. Local and systemic adverse reactions were noted by some trials.

\section{Excluded studies}

See the 'Characteristics of excluded studies' table for details.

\section{Risk of bias in included studies}

See Figure 1 and Figure 2. 
Figure I. Risk of bias summary: review authors' judgements about each risk of bias item for each included study.

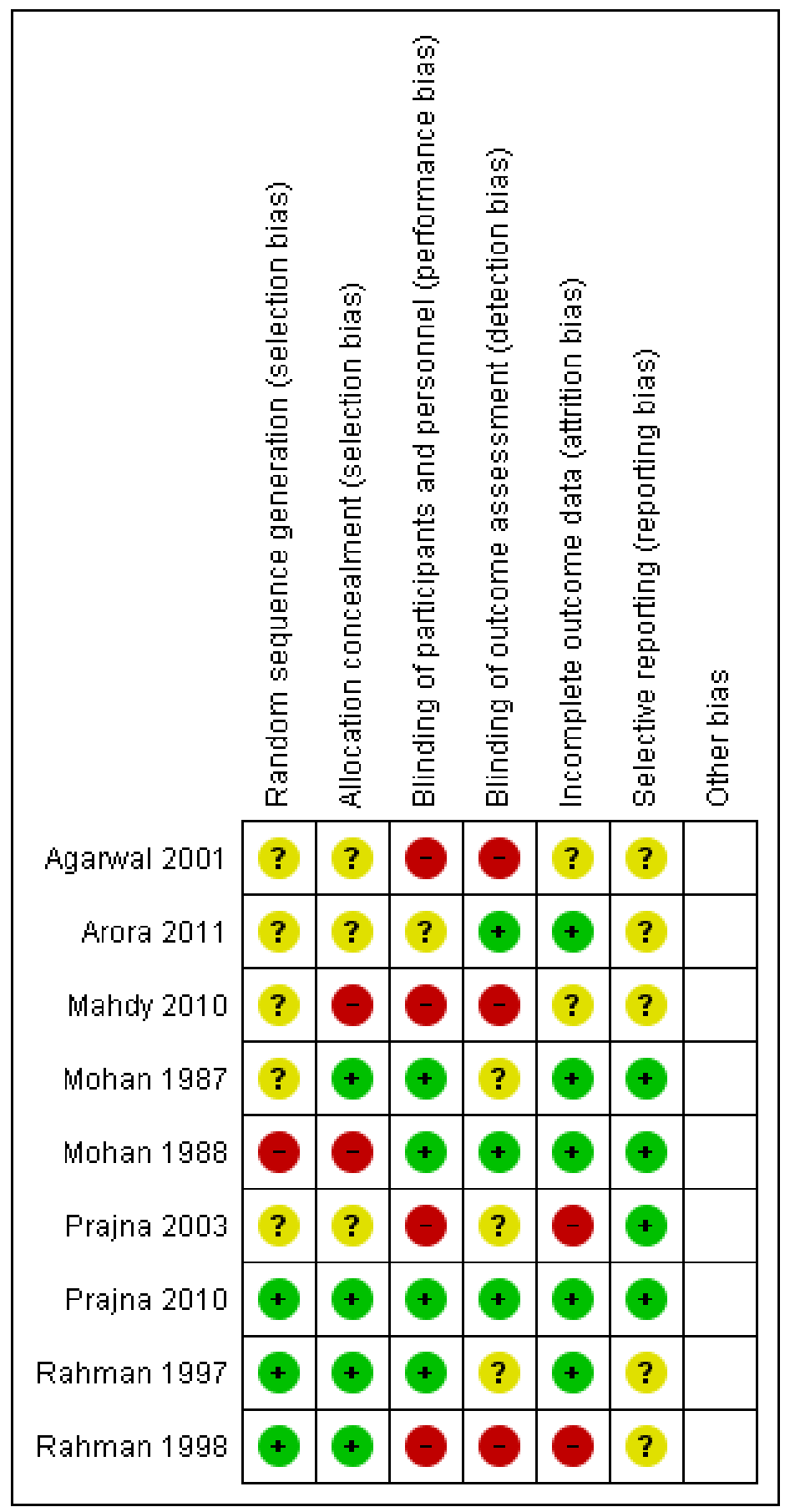

Medical interventions for fungal keratitis (Review)

Copyright $\odot 2012$ The Cochrane Collaboration. Published by John Wiley \& Sons, Ltd. 
Figure 2. Risk of bias graph: review authors' judgements about each risk of bias item presented as percentages across all included studies.

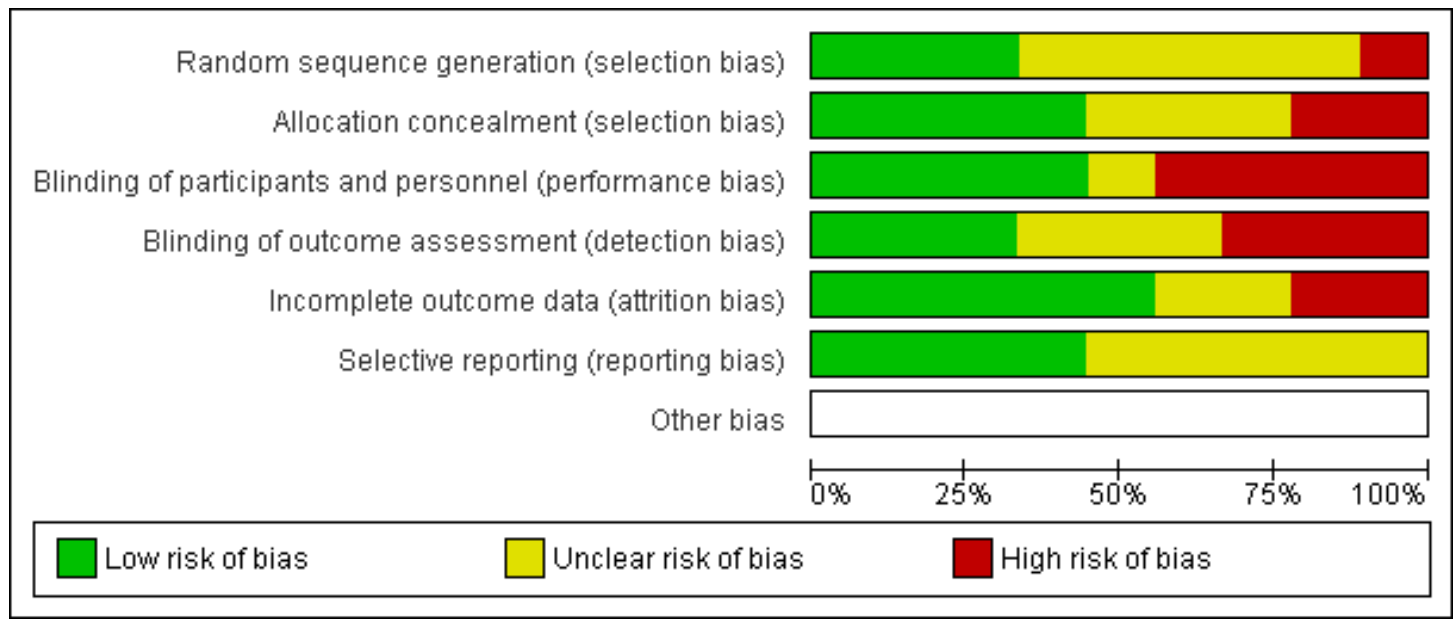

\section{Allocation}

Only three trials reported adequate methods of sequence generation and allocation concealment (Prajna 2010; Rahman 1997; Rahman 1998).

\section{Blinding}

Masking of participants was not always possible. Only Mohan 1988 and Prajna 2010 reported adequate masking of participants, personnel and outcome assessment.

\section{Incomplete outcome data}

Arora 2011, Mohan 1987; Mohan 1988, Prajna 2010 and Rahman 1997 had reasonably complete data. In the other studies, attrition bias was considered to be possible.

\section{Selective reporting}

Selective reporting was not considered to be a major problem in the included trials but it was not always possible to assess this adequately.

\section{Other potential sources of bias}

Trials by Mohan 1987, Mohan 1988 and Agarwal 2001 were crossover trials which can be a potential source of bias.

\section{Effects of interventions}

\section{Treatment failure}

1. Topical itraconazole versus topical and systemic itraconazole The combination of topical (1\%) and oral intraconazole (100 mg twice daily for three weeks) did not appear to confer any additional advantage to itraconazole alone (Agarwal 2001) with a relative risk (RR) of 1.0; 95\% confidence internal (CI) 0.37 to 2.71 .

2. Silver sulphadiazine versus miconazole

The results of two studies by the same author (Mohan 1987; Mohan 1988) indicated that silver sulphadiazine was more effective than miconazole, however, the confidence intervals were wide and the results were also compatible with a greater efficacy of miconazole. Mohan 1987: silver sulphadiazine (0.5\% and $1 \%$ ) compared to $1 \%$ miconazole gave a RR (of failure, i.e. not healing of ulcer) of 0.63 ; $95 \%$ CI 0.21 to 1.83 . Mohan $19881 \%$ silver sulphadiazine ointment compared to $1 \%$ miconazole ointment: RR $0.44 ; 95 \%$ CI 0.16 to 1.21 . The pooled estimate of these two trials was 0.51 (95\% CI 0.25, 1.07) (Analysis 1.1).

3. Econazole versus natamycin

In Prajna 2003, there appeared to be little difference in the effects of econazole and natamycin: RR 0.99: 95\% CI 0.8 to 1.21 .

4. Chlorhexidine gluconate versus natamycin

In two trials by the same investigators (Rahman 1997; Rahman 1998) there was some evidence for a favourable effect of chlorhex- 
idine compared to natamycin in response at five days (Analysis 2.1), however, the results on healing of the ulcer at 21 days was less conclusive (Analysis 2.2).

5. Voriconazole versus natamycin

Arora 2011 and Prajna 2010 found no evidence for any difference between these two antifungal agents. However, Arora 2011 was rather small and it was not possible to combine the results of these studies because of differences in outcomes presented. Prajna 2010 found that people treated with voriconazole had a 1 line better best correct visual acuity compared to people treated with natamycin at three months, however, this difference was not statistically significant.

6. Amphotericin B combined with fluconazole (subconjunctival injection)

Mahdy 2010 found a higher proportion of ulcers healed with combination treatment (amphotericin B and fluconazole) (83\%) compared to amphotericin alone (67\%), however. this study was considered to be at relatively high risk of bias (Figure 1).

\section{Adverse reactions}

Mild side effects were noted in topical itraconazole, which included:

1. corneal oedema in two cases;

2. increased intraocular pressure in two cases; and

3. prolonged congestion in four cases.

On the other hand, no significant side effects were reported in patients with oral itraconazole.

Mild local allergic reactions were observed in three eyes using silver sulphadiazine ointment as reported in Mohan 1988.

Prajna 2003 did not elaborate on the ocular and systemic adverse reactions due to $2 \%$ econazole and $5 \%$ natamycin. No systematic adverse effects were recorded in Prajna 2010. There were nine corneal perforations in the natamycin group and 10 in the voriconazole group. No adverse reactions to study medications were noted in Arora 2011. In Mahdy 2010 two cases of subconjunctival haemorrhage associated with the injection site were noted but no conjunctival necrosis.

There was no report of significant systemic or ocular adverse reactions from both chlorhexidine gluconate and natamycin. A case of temporary punctate epitheliopathy was observed in one participant receiving chlorhexidine gluconate. This was attributed to increased frequency of application of the drops. No early cataract formation was observed at six months to one year after treatment for participants exposed to chlorhexidine gluconate and natamycin.

\section{DISCUSSION}

This systematic review aimed to provide a critical, quantitative overview of previous clinical research and to yield, where possible, summary effect measures with increased statistical power by combining multiple small clinical trials. The current review includes nine trials comparing different antifungal drugs in topical drops, ointment and oral preparations for the treatment of fungal keratitis. All trials were done in developing countries since the incidence is higher compared to developed countries such as the United States. There are still no large multicentre randomised trials on the treatment of fungal keratitis.

Seven antifungal agents, namely: voriconazole, econazole, itraconazole, miconazole, natamycin, chlorhexidine gluconate and silver sulphadiazine were studied. The latter two are not part of the conventional drugs which act on the hyphal cell membranes. The use of alternative drugs such as chlorhexidine gluconate and silver sulphadiazine may indicate that conventional drugs are not always available, are expensive and ineffective. Since fungal keratitis is more common in developing countries the use of inexpensive alternative drugs is promising. In addition, a less financial incentive has been offered to pharmaceutical companies to invest in the development of ocular antifungal agents. The only commercially available antifungal drug in the United States in ophthalmic form is natamycin (Natacyn 5\% by Alcon Laboratories). In Asia and Africa, Natacyn is given as a service drug but with limited availability. In India, topical natamycin is manufactured by a local pharmaceutical company, however, no clinical trials have been done on this drug.

Three pairs of trials had the same primary author. One pair compared different concentrations of the drug chlorhexidine gluconate with natamycin, while the other pair compared different concentrations of silver sulphadiazine with miconazole. Succeeding studies may have based the concentration of the study drug from the previous trials. The other pair considered different formulations.

Although natamycin was used as the control drug in four of the six trials, it is not yet considered as the gold standard for treatment for fungal ulcer because of low success rate.

Comparing treatment effects of all the drug preparations studied, silver sulphadiazine ointment has the lowest proportion of participants with treatment failure followed by itraconazole in both treatment arms, miconazole ointment, chlorhexidine gluconate, econazole. The drug with the highest failure proportion with failed ulcer was natamycin (2.5\% and 5\%). However, these comparisons between treatment arms of different studies do not represent randomised comparisons (it is effectively an observational study), thus these differences may reflect differences in the different populations studied.

\section{Summary of main results}

Based on the nine trials included in this review, there is no evidence that any particular drug, or combination of drugs, is more effective in the management of fungal keratitis. However, the trials 
included in this review were of variable quality and were generally underpowered.

\section{Overall completeness and applicability of evidence}

The evidence supporting the treatment of fungal keratitis appears to be weak. Only nine trials of variable quality were identified. The trials considered different preparations and comparisons and so it was not possible usefully to pool the data.

Treatment regimens such as amphotericin B and other new drugs such as voriconazole have not yet been studied in a large scale manner.

\section{Quality of the evidence}

The review provides weak evidence for the drugs used in management of fungal keratitis. Nine trials with 568 participants have been included using different antifungal medications. There was no consistent drug of comparison (control). We did not combine results since the drugs used were different.

\section{Potential biases in the review process}

An exhaustive search on the trials was done. However, there are few RCTs on fungal keratitis since the disease is rare in developed countries. Since fungal keratitis is more often studied in developing countries, unpublished reports might have been excluded.

\section{Agreements and disagreements with other studies or reviews}

Most of the trials on management of fungal keratitis gathered during the literature search are case series. Only the RCTs were included in the review.

\section{A U THORS, CONCLUSIONS}

\section{Implications for practice}

The first line of treatment in fungal keratitis is topical antifungal agents. Although it is prudent to wait for culture and sensitivity results before instituting medical therapy, fungi do not grow as fast as bacteria even under well-controlled conditions. Thus, antifungal agents are administered promptly once fungal elements are seen on microbiology examination.

Current antifungal agents used in the treatment of fungal keratitis in the RCTs are varied. Furthermore, the different studies are weak, owing to their small sample size. The results of these studies also did not show a significant difference among the heterogenous interventions. There is little evidence to support the use of any particular drug, or combination of drugs.

\section{Implications for research}

There is a need for future multicentre RCTs with a large sample size and the treatment given can be any of the interventions in the previous RCTs. Since the price of these drugs are likewise prohibitive to patients in developing nations, cost-effectiveness of these drugs should also be examined. The search for a cheaper and more effective treatment alternative to what has already been proposed still continues.

\section{ACKNOW LEDGEMENTS}

The Cochrane Eyes and Vision Group have prepared and will execute the electronic searches. We would like to thank Anupa Shah, Katherine Henshaw, Sally Green, Steve McDonald, Liam Smeeth, Ruben Lim Bon Siong, Leo Cubillan, Alejandro De Leon, Anna Lisa Yu, Johann Michael Reyes, Jaime FlorCruz, Guo Baoqi, Maoling Wei of the Chinese Cochrane Center and Richard Wormald. We would also like to thank the peer reviewers especially Catey Bunce for comments on the review and Mark Wilkins for comments on the protocol.

Richard Wormald (Co-ordinating Editor for CEVG) acknowledges financial support for his CEVG research sessions from the Department of Health through the award made by the National Institute for Health Research to Moorfields Eye Hospital NHS Foundation Trust and UCL Institute of Ophthalmology for a Specialist Biomedical Research Centre for Ophthalmology. The views expressed in this publication are those of the authors and not necessarily those of the Department of Health. 


\section{R E F E R E N C E S}

\section{References to studies included in this review}

Agarwal 2001 \{published data only\}

Agarwal PK, Roy P, Das A, Banerjee A, Maity PK, Banerjee AR. Efficacy of topical and systemic itraconazole as a broadspectrum antifungal agent in mycotic corneal ulcer. A preliminary study. Indian Journal of Ophthalmology 2001; 49(3):173-6.

Arora 2011 \{published data only\}

Arora R, Gupta D. Voriconazole versus natamycin as primary treatment in fungal ulcers. Clinical and Experimental Ophthalmology 2011;39(5):434-40.

Mahdy 2010 \{published data only\} Mahdy RA, Nada WM, Wageh MM. Topical amphotericin $B$ and subconjunctival injection of fluconazole (combination therapy) versus topical amphotericin B (monotherapy) in treatment of keratomycosis. Journal of Ocular Pharmacology and Therapeutics 2010;26(3):281-5.

Mohan 1987 \{published data only\}

Mohan M, Gupta SK, Kalra VK, Vajpayee RB, Sachdev MS. Silver sulphadiazine in the treatment of mycotic keratitis. Indian Journal of Medical Research 1987;85:572-5.

Mohan 1988 \{published data only\}

Mohan M, Gupta SK, Kalra VK, Vajpayee RB, Sachdev MS. Topical silver sulphadiazine - a new drug for ocular keratomycosis. British Journal of Ophthalmology 1988;72 (3):192-5.

Prajna 2003 \{published data only\}

Prajna NV, John RK, Nirmalan PK, Lalitha P, Srinivasan M. A randomised clinical trial comparing $2 \%$ econazole and $5 \%$ natamycin for the treatment of fungal keratitis. British Journal of Ophthalmology 2003;87(10):1235-7.

Prajna 2010 \{published data only\} Prajna NV, Mascarenhas J, Krishnan T, Reddy PR, Prajna L, Srinivasan M, et al.Comparison of natamycin and voriconazole for the treatment of fungal keratitis. Archives of Ophthalmology 2010;128(6):672-8.

Rahman 1997 \{published data only\} Rahman MR, Minassian DC, Srinivasan M, Martin MJ, Johnson GJ. Trial of chlorhexidine gluconate for fungal corneal ulcers. Ophthalmic Epidemiology 1997;4(3):141-9.

Rahman 1998 \{published data only\}

Rahman MR, Johnson GJ, Husain R, Howlader SA, Minassian DC. Randomised trial of $0.2 \%$ chlorhexidine gluconate and $2.5 \%$ natamycin for fungal keratitis in Bangladesh. British Journal of Ophthalmology 1998;82(8): 919-25.

\section{References to studies excluded from this review}

Jones 1975 \{published data only\}

Jones BR. Principles in the management of oculomycosis. XXXI Edward Jackson memorial lecture. American Journal of Ophthalmology 1975;79(5):719-51.
Kalavathy 2002 \{published data only\}

Kalavathy CM, Thomas PA. Efficacy of topical and systemic itraconazole as a broad-spectrum antifungal agent in mycotic corneal ulcer. A preliminary study. Indian Journal of Ophthalmology 2002;50(1):71-2.

Kalavathy 2005 \{published data only\} Kalavathy CM, Parmar P, Kaliamurthy J, Philip VR, Ramalingam MD, Jesudasan CA, et al.Comparison of topical itraconazole $1 \%$ with topical natamycin $5 \%$ for the treatment of filamentous fungal keratitis. Cornea 2005;24 (4):449-52.

Lavingia 1986 \{published data only\} Lavingia B, Dave S. Comparative study of amphotericin-B pimaricin and gentian violet on ocular fungi. Indian Journal of Ophthalmology 1986;34:73-7.

Mabon 1998 \{published data only\} Mabon M. Fungal keratitis. International Ophthalmology Clinics 1998;38(4):115-23.

Mahashabde 1987 \{published data only\} Mahashabde S, Nahata MC, Shrivastava U. A comparative study of anti-fungal drugs in mycotic corneal ulcer. Indian Journal of Ophthalmology 1987;35(5-6):149-52.

Maichuk 1990 \{published data only\} Maichuk I, Karimov MK, Lapshina NA. Ketoconazole in the treatment of ocular mycoses [Ketokonazol v lechenii mikozov glaza]. Vestnik Oftalmologii 1990;106(1):44-6.

Maichuk 1991 \{published data only\} Maichuk I, Lapshina NA, Diadina UV. Midazoles in the treatment of ocular mycoses [Imidazoly v lechenii mikozov glaza]. Antibiotiki i Khimioterapiia 1991;36(1):45-6.

Maichuk 1994 \{published data only\}

Maichuk I, Diadina UV. Itraconazole in the treatment of ophthalmomycoses [Itrakonazol v lechenii oftal'momikozov]. Antibiotiki i Khimioterapiia 1994;39(7): 54-6.

Maichuk 1995 \{published data only\} Maichuk I, Diadina UV. Metamphocin in the treatment of ocular mycoses [Metamfotsin v lechenii mikozov glaza]. Antibiotiki i Khimioterapiia 1995;40(11-12):55-6.

Martin 1996 \{published data only\} Martin MJ, Rahman MR, Johnson GJ, Srinivasan M, Clayton YM. Mycotic keratitis: susceptibility to antiseptic agents. International Ophthalmology 1996;19(5):299-302.

Mitsui 1987 \{published data only\} Mitsui Y, Kitano S, Uchida Y, Tanaka N, Kobayashi $\mathrm{S}$, Tokuda $\mathrm{H}$, et al.Effect of $1 \%$ pimaricin ophthalmic ointment in the treatment of keratomycosis. Nippon Ganka Gakkai Zasshi 1987;91(2):304-11.

Panda 1996 \{published data only\} Panda A, Sharma N, Angra SK. Topical fluconazole therapy of Candida keratitis. Cornea 1996;15(4):373-5. 
Rao 1997 \{published data only\}

Rao SK, Madhavan HN, Rao G, Padmanabhan P. Fluconazole in filamentous fungal keratitis. Cornea 1997; 16(6): 700

Ray 2002 \{published data only\}

Ray A, Rao SK, Fogla R, Padmanabhan P, Kalavathy $\mathrm{CM}$, Thomas PA, et al.Efficacy of topical and systemic itraconazole as a broad-spectrum antifungal agent in mycotic corneal ulcer. A preliminary study. Indian Journal of Ophthalmology 2002;50(1):70-2.

Sun 1996 \{published data only\}

Sun B, He Y, Wang Y. Comparison of various types of imidazole derivatives for treatment of filamentous fungal keratitis. Chung Hua Yen Ko Tsa Chih 1996;32(4):260-3.

Xie 2001 \{published data only\}

Xie L, Dong X, Shi W. Treatment of fungal keratitis by penetrating keratoplasty. British Journal of Ophthalmology 2001;85(9):1070-4.

\section{References to ongoing studies}

NCT00516399 \{published data only\}

NCT00516399. A clinical trial of the treatment of fungal corneal ulcers with povidone-iodine. ClinicalTrials.gov/ show/NCT00516399 (accessed 20 Sept 2011).

NCT00996736 \{published data only\}

NCT00996736. Mycotic Ulcer Treatment Trial I. ClinicalTrials.gov/show/NCT00996736 (accessed 20 Sept 2011).

NCT00997035 \{published data only\}

NCT00997035. Mycotic Ulcer Treatment Trial II. ClinicalTrials.gov/show/NCT00997035 (accessed $20 \mathrm{Sept}$ 2011)

\section{Additional references}

\section{Galarreta 2007}

Galarreta DJ, Tuft SJ, Ramsay A, Dart JK. Fungal keratitis in London: microbiological and clinical evaluation. Cornea 2007;26(9):1082-6.

Glanville 2006

Glanville JM, Lefebvre C, Miles JN, Camosso-Stefinovic J. How to identify randomized controlled trials in MEDLINE: ten years on. Journal of the Medical Library Association 2006; 94(2):130-6.
Gopinathan 2002

Gopinathan U, Garg P, Fernandes M, Sharma S, Athmanathan S, Rao GN. The epidemiological features and laboratory results of fungal keratitis: a 10 year review at a referral eye care center in South India. Cornea 2002;21(6): $555-9$.

Higgins 2011

Higgins JPT, Altman DG, Sterne JAC (editors). Chapter 8: Assessing risk of bias in included studies. In: Higgins JPT, Green S (editors). Cochrane Handbook for Systematic Reviews of Interventions Version 5.1.0 (updated March 2011). The Cochrane Collaboration, 2011. Available from www.cochrane-handbook.org.

Liesegang 1980

Liesegang TJ, Forster RK. Spectrum of microbial keratitis in South Florida. American Journal of Ophthalmology 1980; 90(1):38-47.

O' Brien 1997

O' Brien TP, Rhee P. Pharmacotherapy of fungus infections of the eye. In: Zimmerman TJ, Koonere KS, Fecthner RD, Sharir M editor(s). Textbook of ocular pharmacology. Hagerstown: Lipincott-Raven, 1997:587-607.

O’ Day 1996 O’ Day D. Fungal keratitis. In: Pepose JS editor(s). Ocular infection and immunity. St Louis: Moseby, 1996:1048-61.

\section{Review Manager 2011}

The Nordic Cochrane Centre, The Cochrane Collaboration. Review Manager (RevMan). 5.1. Copenhagen: The Nordic Cochrane Centre, The Cochrane Collaboration, 2011.

Tu 2007

Tu EY, Park AJ. Recalcitrant Beauveria bassiana keratitis: confocal microscopy findings and treatment with posaconazole (Noxafil). Cornea 2007;26(8):1008-10.

\section{Valenton 2000}

Valenton M. Central microbial keratitis. Philippine Journal of Ophthalmology 2000;25(1):10-21.

\section{References to other published versions of this review}

\section{FlorCruz 2008}

FlorCruz NV, Peczon IV. Medical interventions for fungal keratitis. Cochrane Database of Systematic Reviews 2008, Issue 1. [DOI: 10.1002/14651858.CD004241.pub2]

* Indicates the major publication for the study 


\title{
CHARACTERISTICS OF STUDIES
}

\section{Characteristics of included studies [ordered by study ID]}

\author{
Agarwal 2001
}

\begin{tabular}{|c|c|c|}
\hline Methods & \multicolumn{2}{|c|}{$\begin{array}{l}\text { Randomised controlled cross-over trial } \\
\text { Masking: It is impossible to be masked due to systemic intervention compared to topical } \\
\text { only }\end{array}$} \\
\hline Participants & \multicolumn{2}{|c|}{$\begin{array}{l}\text { Setting: Calcutta, India } \\
54 \text { patients divided into } 2 \text { groups. Group I comprised new patients and Group II com- } \\
\text { prised patients who had been previously treated with agents. No inclusion and exclusion } \\
\text { criteria elaborated. Clinically suspected cases were included } \\
\text { Male ( } 69 \%), 50 \% \text { aged } 21 \text { to } 40 \text { years } \\
\text { No participants were reported to be excluded or dropped in the study. Patients were } \\
\text { followed up for } 6 \text { months }\end{array}$} \\
\hline Interventions & \multicolumn{2}{|c|}{$\begin{array}{l}1 \% \text { topical itraconazole versus } 1 \% \text { topical itraconazole and } 100 \mathrm{mg} \text { BID for } 3 \text { weeks } \\
\text { oral itraconazole. Topical itraconazole was prepared by mixing } 100 \mathrm{mg} \text { of itraconazole } \\
\text { powder with } 100 \mathrm{~mL} \text { artificial tear solution. Oral itraconazole was discontinued after } 3 \\
\text { weeks while topical itraconazole was continued for } 6 \text { weeks after resolution of keratitis }\end{array}$} \\
\hline Outcomes & \multicolumn{2}{|c|}{$\begin{array}{l}\text { Main outcome was healing of corneal ulcer, within } 6 \text { weeks. Favourable response was } \\
\text { further graded based on corneal opacity and visual acuity. Other parameters included } \\
\text { residual corneal opacity, best corrected visual acuity and rate of improvement. Side effects } \\
\text { such as oedema, glaucoma and congestion were also reported if present }\end{array}$} \\
\hline Notes & \multicolumn{2}{|c|}{$\begin{array}{l}\text { This is a preliminary study. Aspergillus was common etiology found. Fusarium was not } \\
\text { responsive to itraconazole }\end{array}$} \\
\hline \multicolumn{3}{|l|}{ Risk of bias } \\
\hline Bias & Authors' judgement & Support for judgement \\
\hline $\begin{array}{l}\text { Random sequence generation (selection } \\
\text { bias) }\end{array}$ & Unclear risk & $\begin{array}{l}\text { "The patients were divided into two groups" } \\
\text { on the basis of new and untreated patients } \\
\text { but no other information is given }\end{array}$ \\
\hline Allocation concealment (selection bias) & Unclear risk & Not reported \\
\hline $\begin{array}{l}\text { Blinding of participants and personnel } \\
\text { (performance bias) } \\
\text { All outcomes }\end{array}$ & High risk & Not reported but treatments different \\
\hline
\end{tabular}

Blinding of outcome assessment (detection High risk

Not reported but treatments different bias)

All outcomes

Medical interventions for fungal keratitis (Review) 
Agarwal 2001 (Continued)

\begin{tabular}{l|ll}
$\begin{array}{l}\text { Incomplete outcome data (attrition bias) } \\
\text { All outcomes }\end{array}$ & Unclear risk & Not possible to assess \\
\hline Selective reporting (reporting bias) & Unclear risk & Not possible to assess \\
\hline
\end{tabular}

\section{Arora 2011}

\begin{tabular}{ll}
\hline Methods & Randomised controlled trial \\
\hline Participants & $\begin{array}{l}\text { Setting: Tertiary care hospital in India } \\
30 \text { people with fungal keratitis, confirmed by microbiology } \\
\text { Predominantly male (group A 67\% male, group B 73\% male). Average age 37.9 (15.1) } \\
\text { years in group A and 48.5 (13.5) years in group B }\end{array}$ \\
\hline Interventions & $\begin{array}{l}\text { 5\% natamycin versus } 1 \% \text { voriconazole. Patients were followed up for a minimum of } 10 \\
\text { weeks, or until complete resolution of the ulcer }\end{array}$ \\
\hline Outcomes & Resolution of the ulcer and visual acuity \\
\hline Notes &
\end{tabular}

\section{Risk of bias}

\begin{tabular}{|c|c|c|}
\hline Bias & Authors' judgement & Support for judgement \\
\hline $\begin{array}{l}\text { Random sequence generation (selection } \\
\text { bias) }\end{array}$ & Unclear risk & $\begin{array}{l}\text { "This study was randomized, double-masked, interven- } \\
\text { tional, pilot study of patients with fungal keratitis". Meth- } \\
\text { ods, first paragraph } \\
\text { "They were randomly divided into two groups of } 15 \text { patients } \\
\text { using the lottery methods". Methods, first paragraph }\end{array}$ \\
\hline Allocation concealment (selection bias) & Unclear risk & $\begin{array}{l}\text { "Double masking of treatment assignment was achieved by } \\
\text { dispensing the medications in identical opaque bottles and } \\
\text { by having the ward nurses wipe any white residue from the } \\
\text { patient's eye prior to study assessment as natamycin is deliv- } \\
\text { ered via suspension, whereas VRC is in solution". Methods, } \\
\text { first paragraph }\end{array}$ \\
\hline $\begin{array}{l}\text { Blinding of participants and personnel } \\
\text { (performance bias) } \\
\text { All outcomes }\end{array}$ & Unclear risk & $\begin{array}{l}\text { "Double masking of treatment assignment was achieved by } \\
\text { dispensing the medications in identical opaque bottles and } \\
\text { by having the ward nurses wipe any white residue from the } \\
\text { patient's eye prior to study assessment as natamycin is deliv- } \\
\text { ered via suspension, whereas VRC is in solution". Methods, } \\
\text { first paragraph }\end{array}$ \\
\hline $\begin{array}{l}\text { Blinding of outcome assessment (detection } \\
\text { bias) } \\
\text { All outcomes }\end{array}$ & Low risk & $\begin{array}{l}\text { "Double masking of treatment assignment was achieved by } \\
\text { dispensing the medications in identical opaque bottles and } \\
\text { by having the ward nurses wipe any white residue from the }\end{array}$ \\
\hline
\end{tabular}




\begin{tabular}{|c|c|c|}
\hline & & $\begin{array}{l}\text { patient's eye prior to study assessment as natamycin is deliv- } \\
\text { ered via suspension, whereas VRC is in solution". Methods, } \\
\text { first paragraph }\end{array}$ \\
\hline $\begin{array}{l}\text { Incomplete outcome data (attrition bias) } \\
\text { All outcomes }\end{array}$ & Low risk & $\begin{array}{l}\text { There were no reported drop outs in both treatment and } \\
\text { control groups. Follow up ranged from } 10 \text { days to } 60 \\
\text { days }\end{array}$ \\
\hline Selective reporting (reporting bias) & Unclear risk & $\begin{array}{l}\text { The primary outcome was defined as the "time taken for } \\
\text { the complete resolution of the ulcer". Methods, last para- } \\
\text { graph } \\
\text { Various other outcomes reported e.g., visual acuity and } \\
\text { mean size of the ulcer }\end{array}$ \\
\hline
\end{tabular}

Mahdy 2010

\begin{tabular}{ll}
\hline Methods & Randomised controlled trial \\
\hline Participants & $\begin{array}{l}\text { Setting: hospital in Egypt } \\
48 \text { people with clinical signs of fungal keratitis } \\
\text { Male }(65 \%) \text {, aged } 15 \text { to } 64 \text { years, average age } 44 \text { years }\end{array}$ \\
\hline Interventions & Topical amphotericin B $(0.5 \mathrm{mg} / \mathrm{ml})$ and subconjunctival fluconazole $(2 \mathrm{mg} / \mathrm{ml})$ com- \\
\hline pared to topical amphotericin B alone
\end{tabular}

\section{Risk of bias}

\begin{tabular}{lll}
\hline Bias & Authors' judgement & Support for judgement \\
\hline $\begin{array}{l}\text { Random sequence generation (selection } \\
\text { bias) }\end{array}$ & Unclear risk & $\begin{array}{l}\text { "The study is a prospective, randomized one,.. " Page 282 } \\
\text { "Eyes with similar clinical and laboratory findings were clas- } \\
\text { sified into } 2 \text { groups of treatment." Page 282 }\end{array}$ \\
\hline
\end{tabular}

\begin{tabular}{|l|l|l|l}
\hline Allocation concealment (selection bias) & High risk & $\begin{array}{l}\text { No description on method of allocation concealment } \\
\text { however the study groups were exactly matched for fun- } \\
\text { gal species (table 2) which is unlikely on this number of } \\
\text { patients if the allocation was truly random }\end{array}$ \\
\hline
\end{tabular}

Blinding of participants and personnel High risk

Participants were not masked (performance bias)

All outcomes 
Mahdy 2010 (Continued)

\begin{tabular}{l|l|l}
$\begin{array}{l}\text { Blinding of outcome assessment (detection } \\
\text { bias) } \\
\text { All outcomes }\end{array}$ & High risk & Outcome assessors were not masked \\
\hline $\begin{array}{l}\text { Incomplete outcome data (attrition bias) } \\
\text { All outcomes }\end{array}$ & Unclear risk & Not reported \\
\hline Selective reporting (reporting bias) & Unclear risk & Difficult to judge from report \\
\hline
\end{tabular}

Mohan 1987

\begin{tabular}{ll}
\hline Methods & $\begin{array}{l}\text { Randomised controlled cross-over trial } \\
\text { Six ulcers had no response. No significant systemic and ocular side effects noted }\end{array}$ \\
\hline Participants & $\begin{array}{l}\text { Setting: New Delhi, India } \\
\text { Included patients were positive for KOH smear } \\
\end{array}$ \\
$\begin{array}{l}30 \text { patients were included; } 10 \text { for } 0.5 \% \text { silver sulphadiazine, } 10 \text { for } 1 \% \text { silver sulphadi- } \\
\text { azine and } 10 \text { for } 1 \% \text { miconazole } \\
\text { Age and sex not reported }\end{array}$
\end{tabular}

Interventions

$0.5 \%$ topical silver sulphadiazine, $1 \%$ topical silver sulphadiazine and $1 \%$ topical miconazole all in ointment form

Outcomes

Main outcome was healing described as absence of fluorescein staining, disappearance of hypopyon, lack of circumcorneal congestion and negative culture

Notes

Silver sulphadiazine had $100 \%$ effectivity in Fusarium ulcers

\section{Risk of bias}

\begin{tabular}{|c|c|c|}
\hline Bias & Authors' judgement & Support for judgement \\
\hline $\begin{array}{l}\text { Random sequence generation (selection } \\
\text { bias) }\end{array}$ & Unclear risk & $\begin{array}{l}\text { "The cases were divided into } 3 \text { treatment } \\
\text { groups [...] on a random basis" Page } 573\end{array}$ \\
\hline Allocation concealment (selection bias) & Low risk & $\begin{array}{l}\text { "The drugs [...were] coded by the Ocular } \\
\text { Pharmacology Laboratory" Page } 573 \\
\text { "At the end of the trial, the code was broken } \\
\text { and the result analyzed" Page } 573\end{array}$ \\
\hline $\begin{array}{l}\text { Blinding of participants and personnel } \\
\text { (performance bias) } \\
\text { All outcomes }\end{array}$ & Low risk & $\begin{array}{l}\text { "Each patient was given a coded antifungal } \\
\text { ointment tube of } 5 g \text { to be applied } 5 \text { times a } \\
\text { day and the entire study was conducted in a } \\
\text { double blind manner" Page } 573\end{array}$ \\
\hline $\begin{array}{l}\text { Blinding of outcome assessment (detection } \\
\text { bias) } \\
\text { All outcomes }\end{array}$ & Unclear risk & $\begin{array}{l}\text { "The drugs [...were] coded by the Ocular } \\
\text { Pharmacology Laboratory" Page } 573\end{array}$ \\
\hline
\end{tabular}

Medical interventions for fungal keratitis (Review)

Copyright @ 2012 The Cochrane Collaboration. Published by John Wiley \& Sons, Ltd. 
Mohan 1987 (Continued)

\begin{tabular}{|c|c|c|}
\hline & & $\begin{array}{l}\text { "Each patient was given a coded antifungal } \\
\text { ointment tube of } 5 g \text { to be applied } 5 \text { times a } \\
\text { day and the entire study was conducted in a } \\
\text { double blind manner" Page } 573 \\
\text { "At the end of the trial, the code was broken } \\
\text { and the result analyzed" Page } 573\end{array}$ \\
\hline $\begin{array}{l}\text { Incomplete outcome data (attrition bias) } \\
\text { All outcomes }\end{array}$ & Low risk & $\begin{array}{l}\text { "There was no fallout from this study on ac- } \\
\text { count of poor patient compliance" Page } 573\end{array}$ \\
\hline Selective reporting (reporting bias) & Low risk & $\begin{array}{l}\text { Probably not a problem as they reported } \\
\text { ulcers responding to treatment }\end{array}$ \\
\hline
\end{tabular}

Mohan 1988

Methods $\quad$ Randomised controlled double masked cross-over trial

Follow-up not stated but rather average healing time. Forty smear positive patients (20

each) were analysed. No reported cases of lost to follow-up

Participants

Setting: New Delhi, India

Included patients were smear positive. No exclusion criteria given

Male $(78 \%)$, aged 14 to 68 years

Interventions

$1 \%$ topical silver sulphadiazine versus $1 \%$ miconazole both in ointment preparations. In absence of improvement in one week, participants were switched to other drug. Interventions were continued for 2 more weeks after healing. Mean days of resolution of ulcers was 20.7 for miconazole and 23.9 for silver sulphadiazine

Outcomes

Healing is described as disappearance of hypopyon and circumcorneal congestion, absence of staining and a negative report for culture. Local and systemic adverse effects were noted

Notes

Ulcers were graded based on size and hypopyon. On cross-over, miconazole resistant fusarium ulcers were healed by silver sulphadiazine. Aspergillus was the most common etiologic agent

\section{Risk of bias}

\begin{tabular}{l|l|l} 
Bias & Authors' judgement & Support for judgement \\
\hline $\begin{array}{l}\text { Random sequence generation (selection } \\
\text { bias) }\end{array}$ & High risk & $\begin{array}{l}\text { "The patients were assigned alternately to } \\
\text { each of two groups" Page 192 }\end{array}$ \\
\hline Allocation concealment (selection bias) & High risk & $\begin{array}{l}\text { Not reported but as sequence was alternate } \\
\text { allocation we have assumed that conceal- } \\
\text { ment was not possible }\end{array}$
\end{tabular}




\section{Mohan 1988 (Continued)}

\begin{tabular}{|c|c|c|}
\hline $\begin{array}{l}\text { Blinding of participants and personnel } \\
\text { (performance bias) } \\
\text { All outcomes }\end{array}$ & Low risk & $\begin{array}{l}\text { "The two ointments were coded and supplied } \\
\text { to the patients in identical packings." Page } \\
192 / 193 \\
\text { "At the end of the study the code was broken } \\
\text { and the results analyzed" Page } 193\end{array}$ \\
\hline $\begin{array}{l}\text { Blinding of outcome assessment (detection } \\
\text { bias) } \\
\text { All outcomes }\end{array}$ & Low risk & $\begin{array}{l}\text { "At the end of the study the code was broken } \\
\text { and the results analyzed" Page } 193\end{array}$ \\
\hline $\begin{array}{l}\text { Incomplete outcome data (attrition bias) } \\
\text { All outcomes }\end{array}$ & Low risk & $\begin{array}{l}\text { "Three patients (two on miconazole and one } \\
\text { on silver sulphadiazine) developed local al- } \\
\text { lergic reactions, possibly due to the ointment } \\
\text { base. They were excluded from further analy- } \\
\text { sis and do not form part of the study material" } \\
\text { Page } 193 \\
\text { Low risk of bias recorded here as this is quite } \\
\text { a low proportion with missing data and was } \\
\text { distributed between the two groups }\end{array}$ \\
\hline Selective reporting (reporting bias) & Low risk & $\begin{array}{l}\text { Probably not a problem as reported ulcers } \\
\text { responding to treatment }\end{array}$ \\
\hline
\end{tabular}

Prajna 2003

Methods

Participants
Randomised controlled trial

2 patients were lost to follow up in both groups

Setting: Aravind, India

Included patients with smear and culture positive for fungal infection were included.

Other inclusion criteria includes size of ulcer at least $2 \mathrm{~mm}^{2}$ and not more than $60 \mathrm{~mm}^{2}$.

Excluded were patients who did not consent to study and did not meet inclusion criteria.

116 participants included

Male (64\%), age range 7 to 84 years, average age 37 (13.8) years

Interventions

$2 \%$ econazole and 5\% natamycin in topical eye drops/ suspension. Atropine sulfate ointment were given to both groups

Outcomes

Main outcome is healed ulcer defined as completely healed epithelial defect with no fluorescein staining, non progression of stromal infiltration

Notes

Follow duration was 4 weeks

\section{Risk of bias}

\section{Bias}

Authors' judgement
Support for judgement 
Prajna 2003 (Continued)

\begin{tabular}{|c|c|c|}
\hline $\begin{array}{l}\text { Random sequence generation (selection } \\
\text { bias) }\end{array}$ & Unclear risk & $\begin{array}{l}\text { “...subjects were randomized to receive ei- } \\
\text { ther..." Page } 1235\end{array}$ \\
\hline Allocation concealment (selection bias) & Unclear risk & Not reported \\
\hline $\begin{array}{l}\text { Blinding of participants and personnel } \\
\text { (performance bias) } \\
\text { All outcomes }\end{array}$ & High risk & $\begin{array}{l}\text { "Since natamycin is available as a suspension, } \\
\text { and precipitates in the corneal tissue, it was } \\
\text { not possible to mask the investigator to the } \\
\text { drugs used on subsequent visits." Page } 1235\end{array}$ \\
\hline $\begin{array}{l}\text { Blinding of outcome assessment (detection } \\
\text { bias) } \\
\text { All outcomes }\end{array}$ & Unclear risk & $\begin{array}{l}\text { "Since natamycin is available as a suspension, } \\
\text { and precipitates in the corneal tissue, it was } \\
\text { not possible to mask the investigator to the } \\
\text { drugs used on subsequent visits." Page } 1235\end{array}$ \\
\hline $\begin{array}{l}\text { Incomplete outcome data (attrition bias) } \\
\text { All outcomes }\end{array}$ & High risk & $\begin{array}{l}\text { "Four of the } 116 \text { patients randomized at base- } \\
\text { line did not return for further follow-up (Fig } \\
\text { 1) and were dropped from the study." Page } \\
1236 \\
\text { However this contradicts figure } 1 \text { where } 5 \\
\text { people lost to follow-up by week } 4 \text {. Also } \\
\text { large numbers of people "exited" the study } \\
\text { due to clinical worsening or reaction to } \\
\text { drops. By week } 425 / 61 \text { in the econazole } \\
\text { group and } 22 / 55 \text { of natamycin group re- } \\
\text { mained in the study }\end{array}$ \\
\hline Selective reporting (reporting bias) & Low risk & $\begin{array}{l}\text { Reported "time to cure" and no indication } \\
\text { of any unreported variables }\end{array}$ \\
\hline
\end{tabular}

\section{Prajna 2010}

\begin{tabular}{ll}
\hline Methods & Multicentre double masked randomised controlled trial \\
\hline Participants & $\begin{array}{l}120 \text { people with fungal keratitis at Aravind Eye Hospital, India } \\
\text { Male }(66 \%), \text { average age in each of four study groups ranged from } 45 \text { to } 50 \text { years }\end{array}$ \\
\hline Interventions & Topical natamycin versus topical voriconazole \\
\hline Outcomes & $\begin{array}{l}\text { Best spectacle-corrected visual acuity at } 3 \text { months. Other outcomes included scar size, } \\
\text { perforations }\end{array}$ \\
\hline Notes & \\
\hline
\end{tabular}

\section{Risk of bias}

Bias

Authors' judgement

\section{Support for judgement}


Prajna 2010 (Continued)

Random sequence generation (selection Low risk bias)
"This study was a randomized, doublemasked, clinical trial of patients with fungal corneal ulcers." Page 673

"Patients were block randomized in groups of 4 (using the statistical package $R$; http: // www.r-project.org) by T.P." Page 673

Allocation concealment (selection bias) Low risk

Blinding of participants and personnel Low risk (performance bias)

All outcomes

Blinding of outcome assessment (detection Low risk bias)

All outcomes

Incomplete outcome data (attrition bias) Low risk All outcomes
"Double-masking of treatment assignment was achieved by dispensing the medications in identical opaque bottles and by having the ward nurses wipe any white residue from the patient's eye prior to study assessment. In addition, patients were no longer receiving treatment at 3 months, the time that the primary outcome of final visual acuity was measured. Only the biostatisticians responsible for the randomization coding and the study pharmacist were unmasked." Page 673

"Double-masking of treatment assignment was achieved by dispensing the medications in identical opaque bottles and by having the ward nurses wipe any white residue from the patient's eye prior to study assessment. In addition, patients were no longer receiving treatment at 3 months, the time that the primary outcome of final visual acuity was measured. Only the biostatisticians responsible for the randomization coding and the study pharmacist were unmasked." Page 673

"Double-masking of treatment assignment was achieved by dispensing the medications in identical opaque bottles and by having the ward nurses wipe any white residue from the patient's eye prior to study assessment. In addition, patients were no longer receiving treatment at 3 months, the time that the primary outcome of final visual acuity was measured. Only the biostatisticians responsible for the randomization coding and the study pharmacist were unmasked." Page 673

"Efficacy endpoints were analyzed on an intent-to-treat basis for all randomized patients enrolled in the study. The primary analysis included the actual 3-month data when available and last observation carried forward for 
Prajna 2010 (Continued)

\begin{tabular}{|c|c|c|}
\hline & & $\begin{array}{l}\text { missing values." Page } 674 \\
\text { "Sensitivity analyses were also performed in } \\
\text { which we separately (1) assigned surgical pa- } \\
\text { tients the value } 1.7 \text { instead of } 1.9 \text {, (2) assigned } \\
\text { patients with perforation (but no surgery) the } \\
\text { value } 1.7 \text { or } 1.9 \text { (instead of using last ob- } \\
\text { servation carried forward), (3) analyzed only } \\
\text { patients with complete followup, or (4) used } \\
\text { multiple imputation (recursive random par- } \\
\text { titioning-based hot deck method)" Page } 674 \\
11 / 120 \text { lost to follow-up but evenly dis- } \\
\text { tributed across study groups } 2 / 2 / 4 / 3\end{array}$ \\
\hline Selective reporting (reporting bias) & Low risk & $\begin{array}{l}\text { "The primary efficacy endpoint was BSCVA } \\
\text { at } 3 \text { months in the study eye, using a lin- } \\
\text { ear regression model with 3-month logMAR } \\
\text { BSCVA as the outcome variable and treat- } \\
\text { ment arm (voriconazole vs natamycin) and } \\
\text { enrollment logMAR BSCVA and scraping (yes } \\
\text { or no) as covariates." Page } 674 \\
\text { "Other } \\
\text { prespecified endpoints included BSCVA at } 3 \\
\text { weeks, adjusting for enrollment BSCVA, and } \\
\text { infiltrate/scar size at } 3 \text { weeks and } 3 \text { months, } \\
\text { adjusting for enrollment infiltrate/scar size." } \\
\text { Page } 674\end{array}$ \\
\hline
\end{tabular}

Rahman 1997

Methods

Randomised controlled double masked trial. Two patients were lost to follow-up after randomisation for unknown reasons. Follow-up was at least 21 days

Participants

Setting: Aravind Eye Hospital in Madurai, India

Included patients were smear positive for hyphal elements

Excluded were patients with only one eye, patients with diabetes mellitus, polymicrobial infections, those unwilling to participate fully or attend for follow up, children under 1 year of age and perforated ulcers

Male $(76 \%)$, aged 50 years and above $(33 \%)$

Interventions

Concentration of chlorhexidine gluconate was varied $(0.05 \%, 0.1 \%$ and $0.2 \%)$ compared to $5 \%$ natamycin. Rescue drugs is given if there is no improvement at 5 days

Outcomes

Outcome measures were response at 5 days, cure by day 21 and toxicity. Favorable response was defined as relief of symptoms, improvement of at least one the following signs of inflammation. Healing at 21 days characterised as intact epithelium, with or without scar formation, but no perforation, anterior staphyloma, no adherent leukoma, no fluorescein staining, no hypopyon and improvement of vision or vision no worse than

Medical interventions for fungal keratitis (Review)

Copyright @ 2012 The Cochrane Collaboration. Published by John Wiley \& Sons, Ltd. 
Rahman 1997 (Continued)

baseline

Notes Data was also stratified based on severity of ulcers. Twelve patients with severe ulcers were excluded in the analysis of outcome at 21 days since only 1 (from chlorhexidine gluconate $0.05 \%$ ) had favourable response. Fusarium was the most common etiologic agent cultured

Risk of bias

\begin{tabular}{|c|c|c|}
\hline Bias & Authors' judgement & Support for judgement \\
\hline $\begin{array}{l}\text { Random sequence generation (selection } \\
\text { bias) }\end{array}$ & Low risk & $\begin{array}{l}\text { "The randomization was computer generated } \\
\text { by statisticians at Aravind, using the one-sam- } \\
\text { ple run test." Page } 143\end{array}$ \\
\hline Allocation concealment (selection bias) & Low risk & $\begin{array}{l}\text { “...60 consecutive patients were randomly } \\
\text { allocated in a double-masked fashion.." Page } \\
142 \\
\text { "The bottles were prepared and labelled only } \\
\text { with the randomized numbers by the Aravind } \\
\text { executive staff Page } 143\end{array}$ \\
\hline
\end{tabular}

Blinding of participants and personnel Low risk (performance bias)

“...60 consecutive patients were randomly All outcomes allocated in a double-masked fashion.." Page 142

"The bottles were prepared and labelled only with the randomized numbers by the Aravind executive staff Page 143

Blinding of outcome assessment (detection Unclear risk bias)

All outcomes
“...60 consecutive patients were randomly allocated in a double-masked fashion.." Page 142

"The bottles were prepared and labelled only with the randomized numbers by the Aravind executive staff Page 143

But for "treatment failures" the code was broken on day 5 so presumably all assessments after that date were unmasked

"Two patients were lost to follow-up, so that 58 patients were left in the study" Page 144

All outcomes

Low risk

Unclear risk
A number of different outcome measures reported and no indication as to whether these were all outcomes on which data collected 
Methods

Participants

Interventions
Randomised controlled trial with follow up at least 6 months. Seventy one patients were eligible but one was excluded because it was a mixed infection. Seventy patients were randomised to two arms 35 each. Six patients (3 on each arms) were dropped due to incomplete follow-up. Only 32 were assessed at 21 days

Setting: Bangladesh

Included patients where smear positive for hyphal elements. Excluded were patients with only one eye, patients with diabetes mellitus, polymicrobial infections, those unwilling to participate fully or attend for follow up, children under 1 year of age and perforated ulcers

Male (74\%), aged 50 to 75 years $(26 \%)$

$0.2 \%$ chlorhexidine gluconate drops prepared from $20 \%$ solution compared to $2.5 \%$ natamycin

Source of natamycin from the EITC Chittagong. Both drops were given one drop hourly for first 3 hours, then hourly for 2 days, 2 hourly for 5 days, and 3 hourly for 2 weeks - a total of three weeks. No improvement at 5 days was assessed as treatment failure. Rescue drugs were given

Outcomes

Healing at 21 days characterised as intact epithelium, with or without scar formation, but no perforation, anterior staphyloma, no adherent leukoma, no fluorescein staining, no hypopyon and improvement of vision or vision no worse than baseline

Divided analysis to smear positive and culture positive cases

Toxicity to drug and cataract were also assessed on long term follow-up

Notes

This is a follow-up study done by Rahman. Chlorhexidine gluconate $0.2 \%$ was used based on the previous study. Ulcers were graded based on size of ulcer. Classified severe if size is greater than $6 \mathrm{~mm}$. Aspergillus and Fusarium were the two most common etiology

\section{Risk of bias}

\section{Bias}

Random sequence generation (selection Low risk bias)

Allocation concealment (selection bias) Low risk

\section{Support for judgement}

"The randomization of individuals was computer generated in London...." Page 920

"... and the codes for the alternative treatments sealed in serially numbered opaque envelopes, which were opened in sequence by the research ophthalmologist as the trial progressed." Page 920

"It was not possible to mask the ophthalmologist or nurses to the medications because of their different appearances" Page 920 Blinding of participants not stated directly but can be inferred that they were masked 
Rahman 1998 (Continued)

\begin{tabular}{l|l|l}
$\begin{array}{l}\text { Blinding of outcome assessment (detection } \\
\text { bias) } \\
\text { All outcomes }\end{array}$ & High risk & $\begin{array}{l}\text { "It was not possible to mask the ophthalmol- } \\
\text { ogist or nurses to the medications because of } \\
\text { their different appearances" Page } 920\end{array}$ \\
\hline $\begin{array}{l}\text { Incomplete outcome data (attrition bias) } \\
\text { All outcomes }\end{array}$ & High risk & $\begin{array}{l}13 / 35 \text { of chlorhexidine } 0.2 \% \\
\text { dropped out of the study by } 21 \text { days com- } \\
\text { pared to } 3 / 36 \text { of the natamycin } 2.5 \% \\
\text { group. Page } 921 \text {, figure } 1\end{array}$ \\
\hline Selective reporting (reporting bias) & Unclear risk & $\begin{array}{l}\text { Main outcome was healing at } 21 \text { days of } \\
\text { treatment but other follow-up periods also } \\
\text { available and not clear that this outcome } \\
\text { was pre-specified or not }\end{array}$
\end{tabular}

BID: twice-daily dose

$\mathrm{KOH}$ : potassium hydroxide

Characteristics of excluded studies [ordered by study ID]

\begin{tabular}{|c|c|}
\hline Study & Reason for exclusion \\
\hline Jones 1975 & This is a lecture on the principles in the management of keratomycosis \\
\hline Kalavathy 2002 & The article is a commentary to Agarwal 2001 \\
\hline Kalavathy 2005 & $\begin{array}{l}\text { This is not a RCT. The first fifty consecutive patients received natamycin while the next fifty patients were given } \\
\text { itraconazole }\end{array}$ \\
\hline Lavingia 1986 & This is an in vitro study on antifungal properties of amphotericin B \\
\hline Mabon 1998 & The article is not a RCT but an overview on fungal keratitis \\
\hline Mahashabde 1987 & This is a case series \\
\hline Maichuk 1990 & This is a case series using antifungal agents for different ocular fungal infections \\
\hline Maichuk 1991 & This is a case series using antifungal agents for different ocular fungal infections \\
\hline Maichuk 1994 & This is a case series using antifungal agents for different ocular fungal infections \\
\hline Maichuk 1995 & This is a case series \\
\hline Martin 1996 & The article is an in vitro study \\
\hline
\end{tabular}


(Continued)

\begin{tabular}{|c|c|}
\hline Mitsui 1987 & This is a case series \\
\hline Panda 1996 & It is not a RCT. Six consecutive eyes were treated with topical fluconazole \\
\hline Rao 1997 & It is a commentary to another article \\
\hline Ray 2002 & The article is a another commentary to Agarwal 2001 \\
\hline Sun 1996 & $\begin{array}{l}\text { There was attempt at randomisation. There was no mention of centralised randomisation. Masking of patients } \\
\text { was impossible due to different form of the medication given. Masking of care givers and outcome assessors } \\
\text { was not reported although difficult to perform because the treatments are in different forms (suspension and oil } \\
\text { mixture). There was also no report on drop out rates }\end{array}$ \\
\hline Xie 2001 & This is a retrospective study on severe fungal ulcers which needed penetrating keratoplasty \\
\hline
\end{tabular}

RCT: randomised controlled trial

\section{Characteristics of ongoing studies [ordered by study ID]}

\section{NCT00516399}

\begin{tabular}{|c|c|}
\hline Trial name or title & A Clinical Trial of the Treatment of Fungal Corneal Ulcers With Povidone-Iodine \\
\hline Methods & Randomised controlled trial \\
\hline Participants & People with fungal corneal ulcers \\
\hline Interventions & Povidone-iodine $1.25 \%$ ophthalmic solution compared to natamycin ophthalmic suspension, USP 5\% \\
\hline Outcomes & $\begin{array}{l}\text { Following text from entry on clinicaltrials.gov: } \\
\text { Number of days until disappearance of hypopyon and criteria for recovery and cure are met and subject is discharged } \\
\text { home. Number of treatment failures. Ocular complications from the infection and ocular and systemic complications } \\
\text { from the treatment. [Time Frame: Inferior outcome is defined as cure time under povidone-iodine treatment, which } \\
\text { is at least } 4 \text { days longer than cure time under natamycin, or time until criteria for improvement to hospital discharge } \\
\text { is reached.] [ Designated as safety issue: Yes] }\end{array}$ \\
\hline Starting date & March 2008 \\
\hline Contact information & Sherwin J Isenberg, M.D. isenberg@ucla.edu \\
\hline Notes & $\begin{array}{l}\text { http://clinicaltrials.gov/ct2/show/NCT00516399 } \\
\text { Trial as yet unpublished: completion date September } 2011\end{array}$ \\
\hline
\end{tabular}




\section{NCT00996736}

Trial name or title

Mycotic Ulcer Treatment Trial I (MUTT I)

\begin{tabular}{|c|c|}
\hline Methods & Randomised controlled trial \\
\hline Participants & People with corneal ulcer aged 16 years and older \\
\hline Interventions & Natamycin $5 \%$ compared to voriconazole $1 \%$ \\
\hline Outcomes & 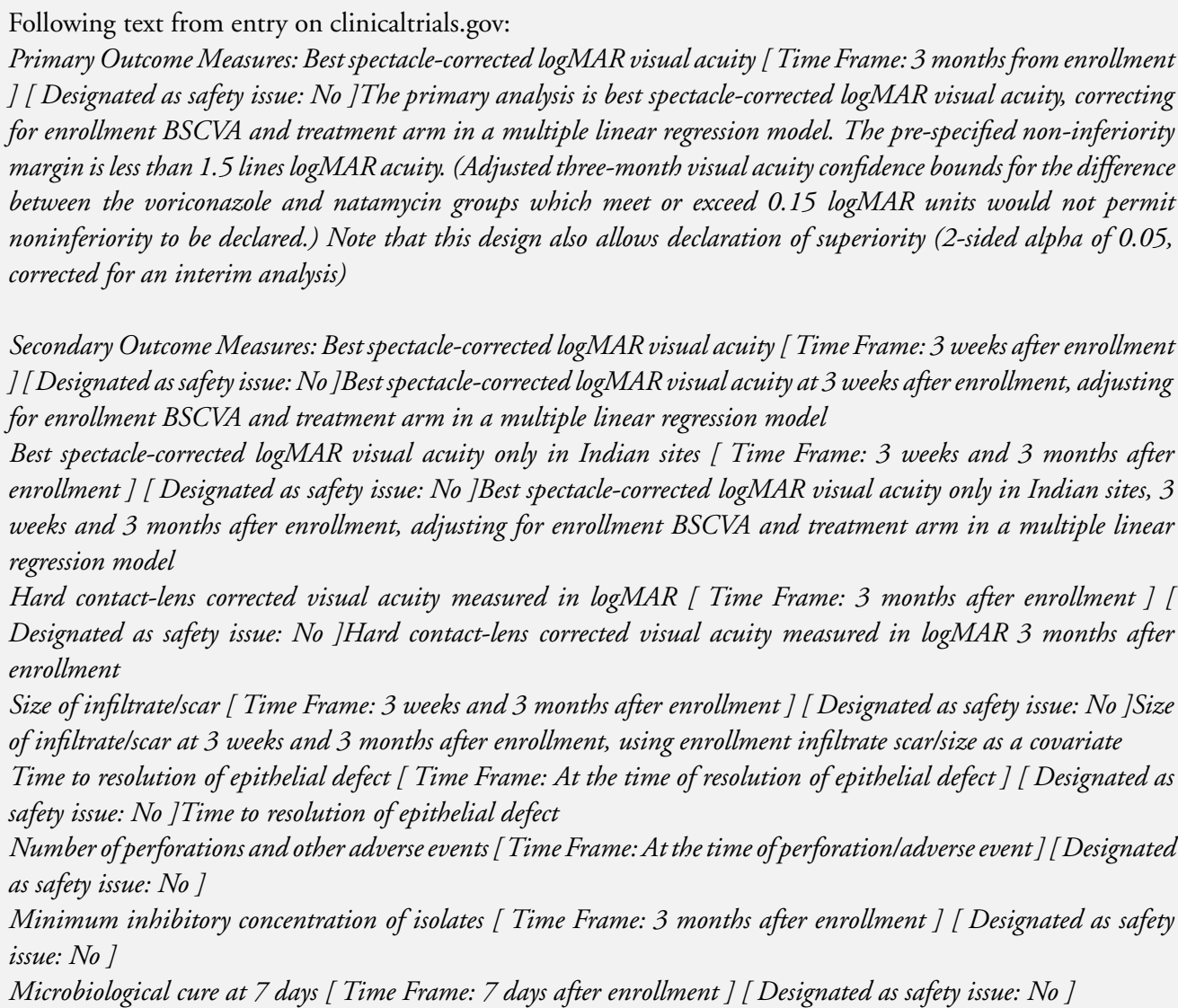 \\
\hline
\end{tabular}

Starting date April 2010

Contact information Tom Lietman, MD tom.lietman@ucsf.edu

Notes http:/clinicaltrials.gov/ct2/show/NCT00996736

Medical interventions for fungal keratitis (Review) 
Trial name or title Mycotic Ulcer Treatment Trial II (MUTT II)

\begin{tabular}{ll}
\hline Methods & Randomised controlled trial \\
\hline Participants & People aged 16 years or older with fungal corneal ulcer \\
\hline Interventions & Topical voriconazole $1 \%$ combined with oral voriconazole compared to topical voriconazole $1 \%$ alone
\end{tabular}

\begin{tabular}{|c|c|}
\hline Outcomes & $\begin{array}{l}\text { Following text from entry on clinicaltrials.gov: } \\
\text { Primary Outcome Measures: Rate of perforation [ Time Frame: } 3 \text { months from enrollment] [ Designated as } \\
\text { safety issue: No ]Comparison of rate of perforation between the treatment groups (topical voriconazole with oral } \\
\text { voriconazole vs. topical voriconazole with oral placebo) } \\
\text { Secondary Outcome Measures: Bestspectacle-corrected logMAR visual acuity [ Time Frame: } 3 \text { weeks after enrollment } \\
\text { ] [Designated as safety issue: No]Bestspectacle-corrected logMAR visual acuity at } 3 \text { weeks after enrollment, adjusting } \\
\text { for enrollment BSCVA and treatment arm in a multiple linear } \\
\text { Best spectacle-corrected logMAR visual acuity only in Indian sites [ Time Frame: } 3 \text { weeks and } 3 \text { months after } \\
\text { enrollment] [ Designated as safety issue: No]Best spectacle-corrected logMAR visual acuity only in Indian sites, } 3 \\
\text { weeks and } 3 \text { months after enrollment, adjusting for enrollment BSCVA and treatment arm in a multiple linear } \\
\text { regression model } \\
\text { Bestspectacle-corrected logMAR visual acuity [ Time Frame: } 3 \text { months after enrollment] [Designated as safety issue: } \\
\text { No]Best spectacle-corrected logMAR visual acuity } 3 \text { months after enrollment, adjustingfor enrollment BSCVA and } \\
\text { treatment arm in a multiple linear } \\
\text { Hard contact-lens corrected visual acuity measured in logMAR [ Time Frame: } 3 \text { months after enrollment ] [ } \\
\text { Designated as safety issue: No ]Hard contact-lens corrected visual acuity measured in logMAR } 3 \text { months after } \\
\text { enrollment } \\
\text { Size of infiltratelscar [ Time Frame: } 3 \text { weeks and } 3 \text { months after enrollment] [ Designated as safety issue: No ]Size } \\
\text { of infiltratelscar at } 3 \text { weeks and } 3 \text { months after enrollment, using enrollment infiltrate scar/size as a covariate } \\
\text { Time to resolution of epithelial defect [ Time Frame: At the time of resolution of epithelial defect] [ Designated as } \\
\text { safety issue: No] } \\
\text { Number of adverse events [ Time Frame: At the time of adverse event] [ Designated as safety issue: No] } \\
\text { Minimum inhibitory concentration of isolates [ Time Frame: } 3 \text { months after enrollment ] [ Designated as safety } \\
\text { issue: No] } \\
\text { Microbiological cure at } 7 \text { days [ Time Frame: } 7 \text { days after enrollment] [ Designated as safety issue: No] }\end{array}$ \\
\hline Starting date & May 2010 \\
\hline Contact information & Nisha Acharya, MD, MS nisha.acharya@ucsf.edu \\
\hline Notes & http://clinicaltrials.gov/ct2/show/NCT00997035 \\
\hline
\end{tabular}


DATA AND ANALYSES

Comparison 1. $1 \%$ silver sulphadiazine versus $1 \%$ miconazole

\begin{tabular}{lcccc} 
Outcome or subgroup title & $\begin{array}{c}\text { No. of } \\
\text { studies }\end{array}$ & $\begin{array}{c}\text { No. of } \\
\text { participants }\end{array}$ & Statistical method & Effect size \\
\hline 1 Ulcer healed at 2 to 4 weeks & 2 & 70 & Risk Ratio (M-H, Fixed, 95\% CI) & $0.51[0.25,1.07]$ \\
\hline
\end{tabular}

Comparison 2. Chlorhexidine versus natamycin

\begin{tabular}{lccll} 
Outcome or subgroup title & $\begin{array}{c}\text { No. of } \\
\text { studies }\end{array}$ & $\begin{array}{c}\text { No. of } \\
\text { participants }\end{array}$ & Statistical method & Effect size \\
\hline 1 Favourable response at 5 days & 2 & 128 & Risk Ratio (M-H, Fixed, 95\% CI) & $0.46[0.28,0.77]$ \\
2 Ulcer healed at 21 days & 2 & 110 & Risk Ratio (M-H, Fixed, 95\% CI) & $0.77[0.55,1.08]$ \\
\hline
\end{tabular}

\section{Analysis I.I. Comparison I I\% silver sulphadiazine versus I\% miconazole, Outcome I Ulcer healed at 2 to 4} weeks.

Review: Medical interventions for fungal keratitis

Comparison: I $1 \%$ silver sulphadiazine versus $1 \%$ miconazole

Outcome: I Ulcer healed at 2 to 4 weeks

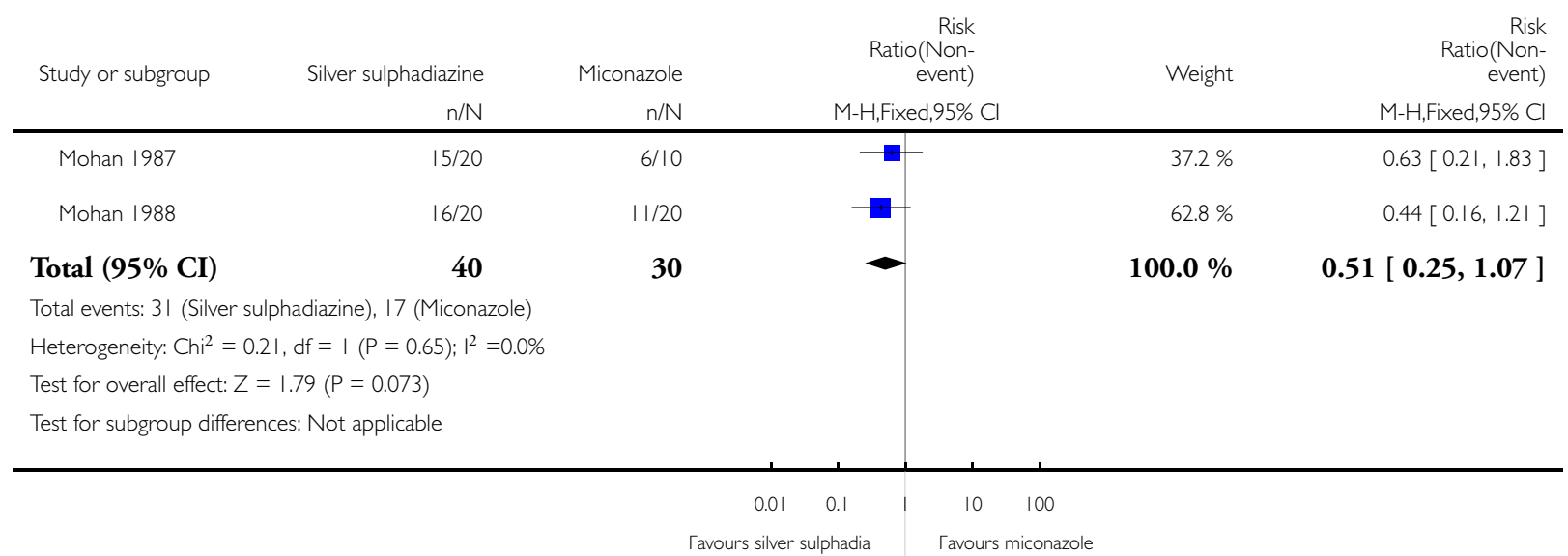


Analysis 2.I. Comparison 2 Chlorhexidine versus natamycin, Outcome I Favourable response at 5 days.

Review: Medical interventions for fungal keratitis

Comparison: 2 Chlorhexidine versus natamycin

Outcome: I Favourable response at 5 days

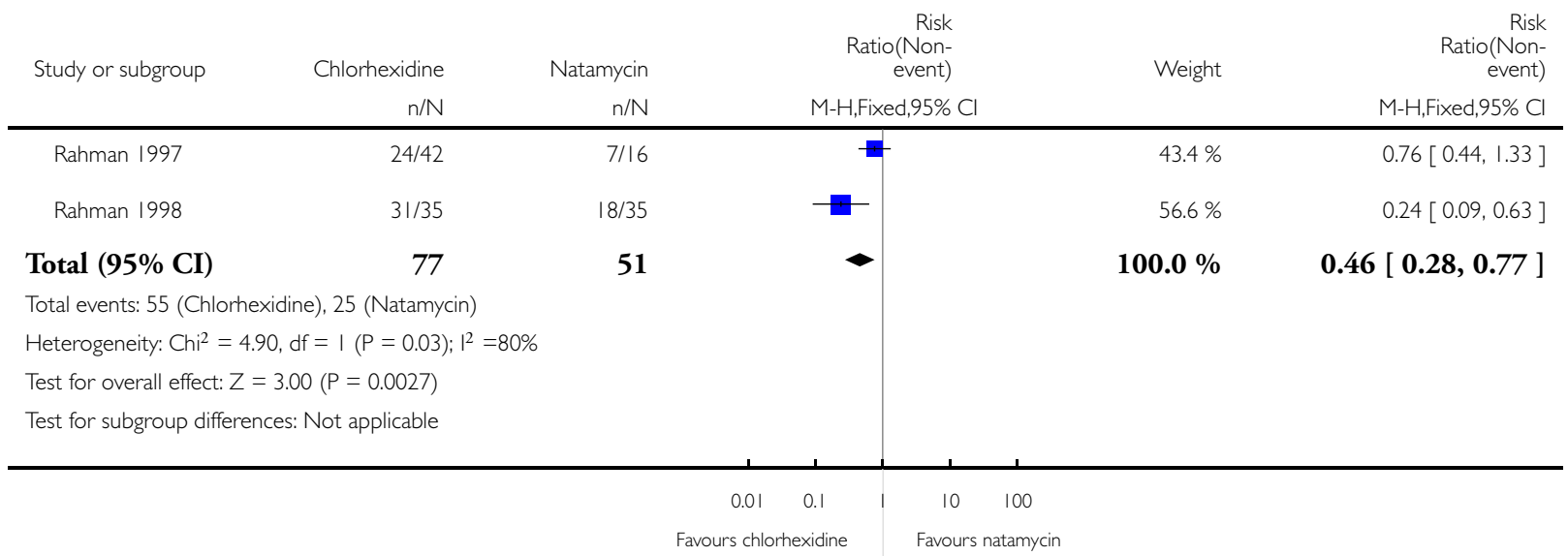

Analysis 2.2. Comparison 2 Chlorhexidine versus natamycin, Outcome 2 Ulcer healed at 21 days.

Review: Medical interventions for fungal keratitis

Comparison: 2 Chlorhexidine versus natamycin

Outcome: 2 Ulcer healed at 21 days

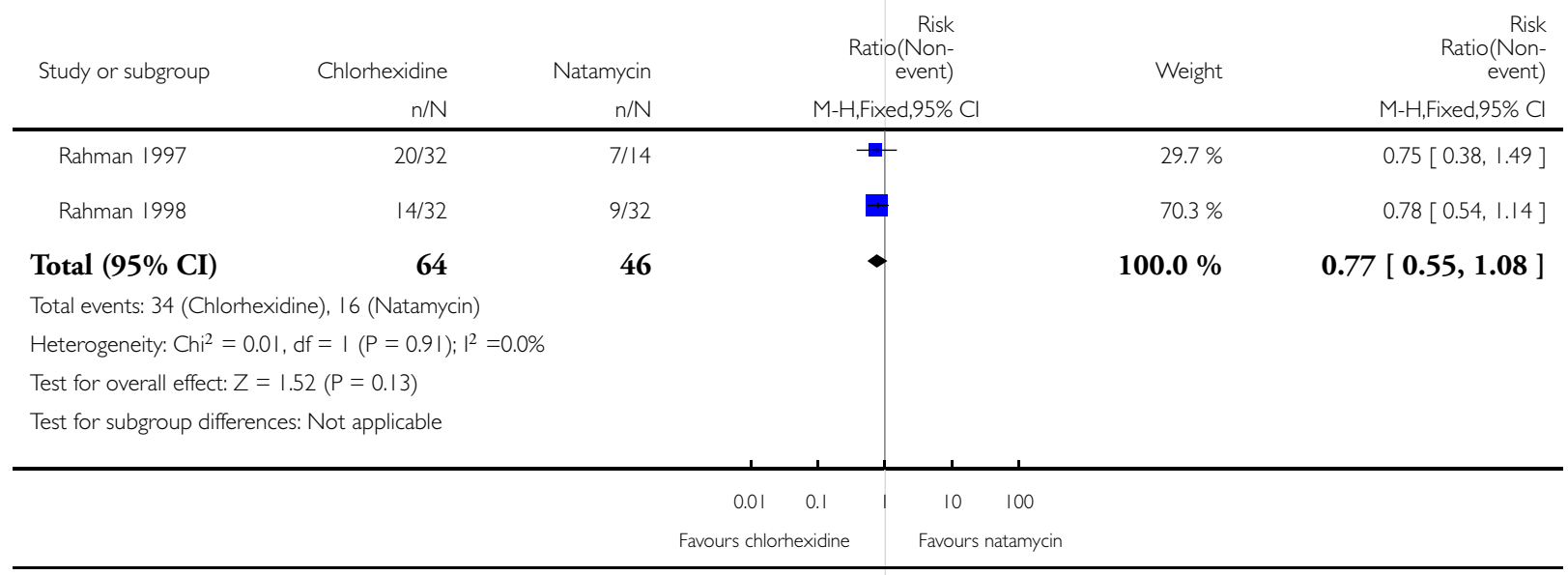

Medical interventions for fungal keratitis (Review)

Copyright @ 2012 The Cochrane Collaboration. Published by John Wiley \& Sons, Ltd. 


\section{ADDITIONAL TABLES}

Table 1. Anti-fungal agents studied in the included trials

\begin{tabular}{|c|c|c|c|c|c|c|}
\hline Study & Intervention & Dose & $\begin{array}{l}\text { Treatment dura- } \\
\text { tion }\end{array}$ & Intervention & Dose & $\begin{array}{l}\text { Treatment dura- } \\
\text { tion }\end{array}$ \\
\hline Agarwal 2001 & $\begin{array}{l}\text { Topical itracona- } \\
\text { zole }\end{array}$ & $1 \%$, every hour & $\begin{array}{l}\text { For } 6 \text { weeks after } \\
\text { keratitis resolved }\end{array}$ & $\begin{array}{l}\text { Oral Itraconazole } \\
\text { Topical itracona- } \\
\text { zole }\end{array}$ & $\begin{array}{l}100 \mathrm{mg} \text { twice } \\
\text { daily } \\
1 \% \text {, every hour }\end{array}$ & $\begin{array}{l}3 \text { weeks } \\
\text { For } 6 \text { weeks after } \\
\text { keratitis resolved }\end{array}$ \\
\hline Arora 2011 & $\begin{array}{l}\text { Topical } \\
\text { natamycin }\end{array}$ & $5 \%$, every hour & $\begin{array}{l}\text { Two weeks } \\
\text { "Further } \\
\text { dosage titrated ac- } \\
\text { cording to the pa- } \\
\text { tient's response" }\end{array}$ & $\begin{array}{l}\text { Topical } \\
\text { voriconazole }\end{array}$ & $1 \%$. every hour & $\begin{array}{l}\text { Two weeks } \\
\text { "Further } \\
\text { dosage titrated ac- } \\
\text { cording to the pa- } \\
\text { tient's response" }\end{array}$ \\
\hline Mahdy 2010 & $\begin{array}{l}\text { Topical ampho- } \\
\text { tericin B } \\
\text { Subconjunc- } \\
\text { tival injection of } \\
\text { fluconazole }\end{array}$ & $\begin{array}{l}0.05 \% \text {, every two } \\
\text { hours } \\
0.5 \mathrm{ml} \text { of } 2 \mathrm{mg} / \\
\mathrm{ml} \text {, daily }\end{array}$ & $\begin{array}{l}? \\
20 \quad \text { in- } \\
\text { jections, first } 10 \\
\text { every day, second } \\
10 \text { every two days }\end{array}$ & $\begin{array}{l}\text { Topical ampho- } \\
\text { tericin B }\end{array}$ & $\begin{array}{l}0.05 \% \text {, every two } \\
\text { hours }\end{array}$ & $?$ \\
\hline Mohan 1987 & $\begin{array}{l}\text { Topical silver sul- } \\
\text { phadiazine }\end{array}$ & $\begin{array}{l}\text { Two doses stud- } \\
\text { ied: } 0.5 \% \text { and } \\
1 \% \text {, applied } 5 \\
\text { times a day }\end{array}$ & $?$ & $\begin{array}{l}\text { Topical micona- } \\
\text { zole }\end{array}$ & $\begin{array}{l}1 \% \text {, applied } 5 \\
\text { times a day }\end{array}$ & $?$ \\
\hline Mohan 1988 & $\begin{array}{l}\text { Topical silver sul- } \\
\text { phadiazine }\end{array}$ & $\begin{array}{l}1 \% \text {, applied } 5 \\
\text { times a day }\end{array}$ & $\begin{array}{l}\text { If no im- } \\
\text { provement after } \\
1 \text { week, switched } \\
\text { to other treat- } \\
\text { ment, treatment } \\
\text { continued for } 2 \\
\text { weeks after clini- } \\
\text { cal healing of ul- } \\
\text { cer }\end{array}$ & $\begin{array}{l}\text { Topical micona- } \\
\text { zole }\end{array}$ & $\begin{array}{l}1 \% \text {, applied } 5 \\
\text { times a day }\end{array}$ & $\begin{array}{l}\text { If no im- } \\
\text { provement after } \\
1 \text { week, switched } \\
\text { to other treat- } \\
\text { ment, treatment } \\
\text { continued for } 2 \\
\text { weeks after clini- } \\
\text { cal healing of ul- } \\
\text { cer }\end{array}$ \\
\hline Prajna 2003 & $\begin{array}{l}\text { Topical } \\
\text { natamycin }\end{array}$ & $\begin{array}{l}5 \% \text {, every hour } \\
\text { between } 7 \text { am and } \\
9 \mathrm{pm}\end{array}$ & Four weeks & $\begin{array}{l}\text { Topical } \\
\text { econazole }\end{array}$ & $\begin{array}{l}2 \% \text {, every hour } \\
\text { between } 7 \mathrm{am} \text { and } \\
9 \mathrm{pm}\end{array}$ & Four weeks \\
\hline Prajna 2010* & $\begin{array}{l}\text { Topical } \\
\text { natamycin }\end{array}$ & $\begin{array}{l}5 \% \text {, every hour } \\
\text { while awake }\end{array}$ & $\begin{array}{l}\text { Ev- } \\
\text { ery hour for one } \\
\text { week followed by } \\
\text { every two hours }\end{array}$ & $\begin{array}{l}\text { Topical } \\
\text { voriconazole }\end{array}$ & $\begin{array}{l}1 \% \text {, every hour } \\
\text { while awake }\end{array}$ & $\begin{array}{l}\text { Ev- } \\
\text { ery hour for one } \\
\text { week followed by } \\
\text { every two hours }\end{array}$ \\
\hline
\end{tabular}

Medical interventions for fungal keratitis (Review) 
Table 1. Anti-fungal agents studied in the included trials (Continued)

\begin{tabular}{|c|c|c|c|c|c|c|}
\hline & & & $\begin{array}{l}\text { for two weeks, } \\
\text { further continua- } \\
\text { tion at discretion } \\
\text { of physician }\end{array}$ & & & $\begin{array}{l}\text { for two weeks, } \\
\text { further continua- } \\
\text { tion at discretion } \\
\text { of physician }\end{array}$ \\
\hline Rahman 1997 & $\begin{array}{l}\text { Topical } \\
\text { natamycin }\end{array}$ & $5 \%$ & $\begin{array}{l}\text { Day 1: Half- } \\
\text { hourly for three } \\
\text { hours, hourly } \\
\text { during } \\
\text { waking hours for } \\
\text { rest of day Days } 2 \\
\text { to } 5 \text { : 2-hourly } \\
\text { Then } \\
\text { 3-hourly for a } \\
\text { further } 2 \text { weeks. } \\
\text { If no improve- } \\
\text { ment at } 5 \text { days } \\
\text { swopped to an- } \\
\text { other treatment }\end{array}$ & $\begin{array}{l}\text { Topi- } \\
\text { cal chlorhexidine } \\
\text { gluconate }\end{array}$ & $\begin{array}{l}\text { Three doses stud- } \\
\text { ied: } 0.05 \%, \quad 0 \text {. } \\
1 \% \text { and } 0.2 \%\end{array}$ & $\begin{array}{l}\text { Day 1: Half- } \\
\text { hourly for three } \\
\text { hours, hourly } \\
\text { during } \\
\text { waking hours for } \\
\text { rest of day Days } 2 \\
\text { to } 5: 2 \text {-hourly } \\
\text { Then } 3- \\
\text { hourly for a fur- } \\
\text { ther } 2 \text { weeksIf no } \\
\text { improvement at } \\
5 \text { days swopped } \\
\text { to another treat- } \\
\text { ment }\end{array}$ \\
\hline Rahman 1998 & $\begin{array}{l}\text { Topical } \\
\text { natamycin }\end{array}$ & $2.5 \%$ & $\begin{array}{l}\text { Half-hourly for } \\
\text { first } 3 \text { hours, then } \\
1 \text { hourly for } 2 \\
\text { days, } \\
\text { hourly for } 5 \text { days, } \\
\text { and } 3 \text { hourly for } \\
3 \text { weeks. If no } \\
\text { improvement at } \\
5 \text { days treatment } \\
\text { changed }\end{array}$ & $\begin{array}{l}\text { Topi- } \\
\text { cal chlorhexidine } \\
\text { gluconate }\end{array}$ & $0.2 \%$ & $\begin{array}{l}\text { Half-hourly for } \\
\text { first } 3 \text { hours, then } \\
1 \text { hourly for } 2 \\
\text { days, } \\
\text { hourly for } 5 \text { days, } \\
\text { and } 3 \text { hourly for } \\
3 \text { weeks. If no } \\
\text { improvement at } \\
5 \text { days treatment } \\
\text { changed }\end{array}$ \\
\hline
\end{tabular}

* Participants were also randomized to "scraping of the corneal epithelium" 


\section{A P P E N D I C E S}

\section{Appendix I. CENTRAL search strategy}

\#1 MeSH descriptor Eye Infections, Fungal

\#2 $\mathrm{MeSH}$ descriptor Keratitis

\#3 fung* near keratit*

\#4 fung* near infect* near eye*

\#5 fung* near infect* near ocular

\#6 keratomycosis

\#7 keratomicosis

\#8 (\#1 OR \#2 OR \#3 OR \#4 OR \#5 OR \#6 OR \#7)

\#9 MeSH descriptor Antifungal Agents

\#10 MeSH descriptor Natamycin

\#11 natamycin*

\#12 MeSH descriptor Chlorhexidine

\#13 chlorhexidine*

\#14 MeSH descriptor Econazole

\#15 econazole*

\#16 MeSH descriptor Itraconazole

\#17 itraconazole*

\#18 MeSH descriptor Miconazole

\#19 miconazole*

\#20 anti fung*

\#21 antifung*

\#22 (\#9 OR \#10 OR\#11 OR \#12 OR \#13 OR \#14 OR \#15 OR \#16 OR \#17 OR \#18 OR \#19 OR \#20 OR \#21)

\#23 (\#8 AND \#22)

\section{Appendix 2. MEDLINE (OVID) search strategy}

1 randomized controlled trial.pt.

2 (randomized or randomised).ab,ti.

3 placebo.ab,ti.

4 dt.fs.

5 randomly.ab,ti.

6 trial.ab,ti.

7 groups.ab,ti.

8 or/1-7

9 exp animals/

10 exp humans/

119 not (9 and 10)

128 not 11

13 exp eye infections, fungal/

14 exp keratitis/

15 (fung\$ adj2 keratit\$).tw.

16 (fung\$ adj3 infect\$ adj3 eye\$).tw.

17 (fung $\$$ adj 3 infect $\$$ adj 3 ocular).tw.

18 keratom?cosis.tw.

19 or/13-18

20 exp antifungal agents/

21 exp natamycin/

22 natamycin $\$ . t w$.

23 exp chlorhexidine/

Medical interventions for fungal keratitis (Review)

Copyright $\odot 2012$ The Cochrane Collaboration. Published by John Wiley \& Sons, Ltd. 
24 chlorhexidine $\$ . t w$.

25 exp econazole/

26 econazole\$.tw.

27 exp itraconazole/

28 itraconazole \$.tw.

29 exp miconazole/

30 miconazole\$.tw.

31 antifung\$.tw.

32 anti fung \$.tw.

33 or/20-32

3419 and 33

3512 and 34

The search filter for trials at the beginning of the MEDLINE strategy is from the published paper by Glanville (Glanville 2006).

\section{Appendix 3. EMBASE (OVID) search strategy}

1 exp randomized controlled trial/

2 exp randomization/

3 exp double blind procedure/

4 exp single blind procedure/

5 random $\$$.tw.

6 or/ $1-5$

7 (animal or animal experiment).sh.

8 human.sh.

97 and 8

107 not 9

116 not 10

12 exp clinical trial/

13 (clin\$ adj3 trial\$).tw.

14 ((singl\$ or doubl\$ or trebl\$ or tripl\$) adj3 (blind $\$$ or mask $\$))$.tw.

15 exp placebo/

16 placebo $\$ . t w$.

17 random\$.tw.

18 exp experimental design/

19 exp crossover procedure/

20 exp control group/

21 exp latin square design/

22 or/ $12-21$

2322 not 10

2423 not 11

25 exp comparative study/

26 exp evaluation/

27 exp prospective study/

28 (control\$ or prospectiv\$ or volunteer\$).tw.

29 or $/ 25-28$

3029 not 10 (930488)

3130 not (11 or 23 )

3211 or 24 or 31

33 exp keratomycosis/

34 exp keratitis/

35 (fung\$ adj2 keratit\$).tw.

36 (fung $\$$ adj3 infect $\$$ adj 3 eye \$).tw.

Medical interventions for fungal keratitis (Review)

Copyright $\odot 2012$ The Cochrane Collaboration. Published by John Wiley \& Sons, Ltd. 
37 (fung $\$$ adj3 infect\$ adj3 ocular).tw.

38 keratom?cosis.tw.

39 or $/ 33-38$

40 exp antifungal agent/

41 exp natamycin/

42 natamycin\$.tw.

43 exp chlorhexidine/

44 chlorhexidine $\$$.tw.

45 exp econazole/

46 econazole $\$ . t w$.

47 exp itraconazole/

48 itraconazole \$.tw.

49 exp miconazole/

50 miconazole $\$$.tw.

51 antifung\$.tw.

52 anti fung $\$$.tw.

53 or/ $40-52$

5439 and 53

5532 and 54

\section{Appendix 4. LILACS search strategy}

eye $\$$ or ocular and fungal keratitis or keratomycosis

\section{Appendix 5. metaRegister of Controlled Trials search strategy}

fungal keratitis

\section{Appendix 6. ClinicalTrials. gov search strategy}

fungal keratitis

\section{WHAT'S NEW}

Last assessed as up-to-date: 29 August 2011.

\begin{tabular}{l|l|l}
\hline Date & Event & Description \\
\hline 15 December 2011 & $\begin{array}{l}\text { New citation required but conclusions have not } \\
\text { changed }\end{array}$ & $\begin{array}{l}\text { Issue 2, 2012: Three new trials were included in the } \\
\text { update (Arora 2011; Mahdy 2010; Prajna 2010). }\end{array}$ \\
\hline 15 December 2011 & New search has been performed & $\begin{array}{l}\text { Issue 2, 2012: Electronic searches were updated, risk of } \\
\text { bias tables have been completed for all included trials } \\
\text { and text modified. A new author joined the review } \\
\text { team to help with updating the review }\end{array}$ \\
\hline
\end{tabular}




\section{H I S T O R Y}

Protocol first published: Issue 2, 2003

Review first published: Issue 1, 2008

\begin{tabular}{lll}
\hline Date & Event & Description \\
\hline 22 October 2008 & Amended & Converted to new review format. \\
\hline 13 November 2007 & New citation required and conclusions have changed & Substantive amendment \\
\hline
\end{tabular}

\section{CONTRIBUTIONSOFAUTHORS}

NVF conceived the review question, co-ordinated the review, organised retrieval of full text copies, wrote to authors of papers for additional information, provided additional data about papers, obtained and screened data on unpublished studies, analysed and interpreted data, performed previous work that was the foundation of the review and wrote the review.

NVF and IP screened initial search results, screened retrieved papers against inclusion criteria, extracted and entered data in to RevMan.

Update Issue 2, 2012

NVF and JE screened search results, appraised quality of papers, extracted and entered data in to RevMan and wrote the update.

\section{DECLARATIONSOF INTEREST}

None known.

\section{SOURCES OF SUPPORT}

\section{Internal sources}

- NIHR/Department of Health, UK.

Funded JE to assist in updating the version published in Issue 2, 2012.

\section{External sources}

- No sources of support supplied 


\section{INDEX TERMS}

\section{Medical Subject Headings (MeSH)}

Antifungal Agents [*therapeutic use]; Eye Infections, Fungal [*drug therapy]; Keratitis [*drug therapy; microbiology]; Randomized Controlled Trials as Topic

\section{MeSH check words}

Humans 